\title{
Substrate-dependent effects of quaternary structure on RNase E activity
}

\author{
Christopher J. Moore, ${ }^{1,5}$ Hayoung Go, ${ }^{1,2,5}$ Eunkyoung Shin, ${ }^{2,5}$ Hye-Jeong $\mathrm{Ha}^{2}{ }^{2}$ Saemee Song, ${ }^{2,3}$ \\ Nam-Chul Ha, ${ }^{3}$ Yong-Hak Kim, ${ }^{4}$ Stanley N. Cohen, ${ }^{1,5}$ and Kangseok Lee ${ }^{2,5}$ \\ ${ }^{1}$ Department of Genetics, Stanford University, Stanford, California 94305, USA; ${ }^{2}$ Department of Life Science, Chung-Ang \\ University, Seoul 06974, Republic of Korea, ${ }^{3}$ Department of Agricultural Biotechnology, Seoul National University, Seoul \\ 08826, Republic of Korea; ${ }^{4}$ Department of Microbiology, Catholic University of Daegu School of Medicine, Daegu 42472, \\ Republic of Korea
}

RNase $E$ is an essential, multifunctional ribonuclease encoded in $E$. coli by the rne gene. Structural analysis indicates that the ribonucleolytic activity of this enzyme is conferred by rne-encoded polypeptide chains that (1) dimerize to form a catalytic site at the protein-protein interface, and (2) multimerize further to generate a tetrameric quaternary structure consisting of two dimerized Rne-peptide chains. We identify here a mutation in the Rne protein's catalytic region (E429G), as well as a bacterial cell wall peptidoglycan hydrolase (Amidase C [AmiC]), that selectively affect the specific activity of the RNase E enzyme on long RNA substrates, but not on short synthetic oligonucleotides, by enhancing enzyme multimerization. Unlike the increase in specific activity that accompanies concentrationinduced multimerization, enhanced multimerization associated with either the E429G mutation or interaction of the Rne protein with AmiC is independent of the substrate's 5' terminus phosphorylation state. Our findings reveal a previously unsuspected substrate length-dependent regulatory role for RNase E quaternary structure and identify cis-acting and trans-acting factors that mediate such regulation.

[Keywords: multimer; degradosome; AmiC; Rne; quaternary structure; RNA stability]

Supplemental material is available for this article.

Received December 5, 2019; revised version accepted December 15, 2020.

The endoribonuclease RNase E (Rne) plays a key role in the degradation and processing of RNAs in Escherichia coli and multiple other bacterial species (for recent reviews, see Carpousis et al. 2009; Mackie 2013; Bandyra and Luisi 2018). The enzyme, which is encoded in E. coli by the rne gene, is normally essential for bacterial proliferation, cleaves single-stranded segments of RNA preferentially in $\mathrm{A}+\mathrm{U}$-rich regions, and is responsive to the extent of $5^{\prime}$ phosphorylation of the targeted RNA (McDowall et al. 1995; McDowall et al. 1996; Mackie 1998; Jiang and Belasco 2004; Garrey et al. 2009; Jourdan et al. 2010; Go et al. 2011). The catalytic function and cleavage site specificity of RNase E reside in the N terminus (NTH-Rne; amino acid residues 1-529) (McDowall et al. 1995), which can be further divided into six subregions: the RNase $\mathrm{H}, \mathrm{S} 1,5^{\prime}$ sensor, DNase I, Zn link, and small domains (Callaghan et al. 2005a).

Polypeptides encoded by rne exist in three functionally discernable forms that differ in quaternary structure (Jiang and Belasco 2004; Callaghan et al. 2005a,b). Crystallographic analysis of NTH-Rne suggests that homodimeri-

\footnotetext{
${ }^{5}$ These authors contributed equally to this work.

Corresponding authors: sncohen@stanford.edu, kangseok@cau.ac.kr Article published online ahead of print. Article and publication date are online at http://www.genesdev.org/cgi/doi/10.1101/gad.335828.119.
}

zation of the polypeptide gene product is necessary for binding of the Rne protein to RNA /Callaghan et al. $2005 a, b)$. Individual Rne protomers associate by the joining of a pair of zinc ion-coordinating structural motifs termed $\mathrm{Zn}$ links (amino acid residues ${ }^{404} \mathrm{CPXCXGXG}^{411}$ ) and interactions between the small domains and RNase $\mathrm{H}$ domains of partner protomers, and pairs of the resulting homodimers are then connected together by "small" domains of protomer components to form tetrameric molecules (Callaghan et al. 2005a). However, rne-encoded peptides lacking the zinc-binding motif and small domain nevertheless retain the normal cleavage site specificity of RNase E, albeit with sharply reduced catalytic activity, and enable E. coli cells lacking the chromosomal rne gene to propagate (Caruthers et al. 2006; Anupama et al. 2011; Kim et al. 2016; Baek et al. 2019), suggesting that an alternative mode for enzyme interaction of Rne molecules with substrates may exist. Consistent with this notion, an NTH-Rne variant that is prevented from forming multimers is catalytically active (Jiang and Belasco 2004).

C 2021 Moore et al. This article is distributed exclusively by Cold Spring Harbor Laboratory Press for the first six months after the full-issue publication date (see http://genesdev.cshlp.org/site/misc/terms.xhtml). After six months, it is available under a Creative Commons License (Attribution-NonCommercial 4.0 International), as described at http://creativecommons.org/licenses/by-nc/4.0/. 
The evolution of an Rne peptide that has the capacity to exist in multiple structural forms raises the prospect that this capacity may enhance biological fitness. To better understand the role of Rne quaternary structure in RNase E function, we sought genetic approaches to investigate quaternary structure. Here, we report the identification of Rne sites and a trans-acting cellular protein that can up-regulate the function of Rne peptides and show that such regulation affects both the enzyme's ribonucleolytic activity disparately on different substrates and its quaternary structure.

\section{Results}

An rne gene mutation that affects quaternary structure of Rne

We used a strategy (Go et al. 2011) that identifies rne gene mutations that increase RNase $\mathrm{E}$ activity in vivo via its effects on cell viability. The screen uses the earlier finding that maintenance of that RNase E activity within a narrow range is required for normal cell proliferation and that either too much or too little activity reduces colony formation. Mutations in RNase E identified by this screen were then evaluated individually for possible effects on quaternary structure. A truncated RNase E variant that contains only the $\mathrm{N}$-terminal 529 amino acid residues of RNase E (NTH-Rne), including the catalytic domain of the enzyme (McDowall and Cohen 1996), is known from crystallographic and biochemical studies to form multimeric molecules (Jiang and Belasco 2004; Callaghan et al. 2005a; Koslover et al. 2008). The C-terminal end of the gene encoding the NTH-Rne protein was attached to a sequence that codes for a hexahistidine tag, and the fusion protein was produced under the control of the isopropyl-thiogalactoside (IPTG)-inducible lacUV5 promoter. Random mutations were introduced into the 398- to 529-amino-acid-encoding segment of this construct, which contains both the $\mathrm{Zn}$ link and small domains involved in multimerization of the enzyme. The construct was devoid of the sequence that enables RNase E autoregulation of its own mRNA (Mudd and Higgins 1993; Jain and Belasco 1995) and was expressed in KSL2000 cells lacking endogenous RNase E (Lee et al. 2002). Clones showing increased ribonucleolytic activity were identified phenotypically (Fig. 1), and the NTH-Rne segment was sequenced. A mutation that substituted a glycine $(\mathrm{G})$ for the originally present glutamic acid (E) at amino acid position 429 of the protein (i.e., clone E429G), which is in a region previously proposed to be at the interface formed in Rne tetramers by interacting dimers (Callaghan et al. 2005a,b), was found; introduction of the same mutation into full-length RNase $\mathrm{E}$ yielded a similar hyperactivity phenotype.

\section{Effect of the E429G mutation on formation}

\section{of higher-order structures and RNA catalysis}

The amino acid residue at Rne position 429 is located in close proximity to the $\mathrm{Zn}$ link motif (amino acid residues
400-415) required for the joining of monomers to form dimers (Callaghan et al. 2005a,b). To determine whether the hyperactivity phenotype observed for the E429G mutation is associated with altered multimer abundance, we examined the population of mutant and wild-type NTH-Rne molecules under the same experimental conditions. An increase in the relative abundance of heterogenic, higher molecular weight enzyme molecules was seen by Western blot analysis of purified UV-crosslinked proteins ( $72 \%$ vs. $38.5 \%$, respectively) after $20 \mathrm{~min}$ of UV exposure (Fig. 1B). Similar results were obtained using a chemical cross-linking reagent $\mathrm{BM}(\mathrm{PEO})_{3}$ (Fig. 1C) that has been employed previously to analyze Rne multimerization (Jiang and Belasco 2004). However, the mutation was associated with only minor changes to the circular dichroism spectrum (Supplemental Fig. S1), suggesting that E429G is not aberrantly folded (Fink 1998; Kelly and Price 2000). Collectively, our results suggested that the E429G mutation leads to an increased abundance of a heterogeneous population of higher-order structures of NTH-Rne. This increase reflected entirely a change in the fraction of molecules that migrate in gels as tetramers, while the fraction migrating as dimers was unchanged (Supplemental Fig. S2A,B), suggesting that dimer to tetramer conversion is at a lower $\mathrm{K}_{\mathrm{d}}$ than monomer-to-dimer conversion (Supplemental Fig. S2C).

An effect of the E429G mutation on multimer formation was supported by the results of an assay that generates a luminescence signal when two subunits of Gaussia princeps luciferase (Gluc) are brought into proximity by interaction between proteins fused to the subunits (Fig. 1D; Remy and Michnick 2006). At all protein concentrations tested, the luminescence signal from E429G Rne-Gluc fusions was greater than the signal from an identical concentration of the E429-Gluc fusion proteins, consistent with the increase in multimer formation observed in crosslinking experiments.

\section{Effect of modifying charge at amino acid residue 429} on higher-order structure and enzyme activity

The E429G mutation results in the substitution of an amino acid having a side chain of neutral electrostatic charge (i.e., glycine, [G]) for a negatively charged amino acid (glutamic acid [E]). Amino acid substitutions that alter electrostatic charge, occurring at the interface between two interacting peptides, can dramatically affect the interaction (for a recent review, see Zhou and Pang 2018). Analysis of the published (Callaghan et al. 2005a) crystal structure of tetrameric NTH-Rne bound to a 13-mer (Fig. 2A) shows that, during multimerization of Rne peptides, the negatively charged side chain of the residue at E429 of each protomer is brought into close proximity to the glutamic acid residue at the 272 position of its dimeric partner (Fig. 2B). This proximity, together with our observation that substitution of glycine $(\mathrm{G})$ for glutamic acid $(\mathrm{E})$ at the 429 position of the Rne protein enhanced the formation of higher-order structures, led us to hypothesize that the E429G mutation may reduce ionic interference between these amino acids, increasing interaction between 
A
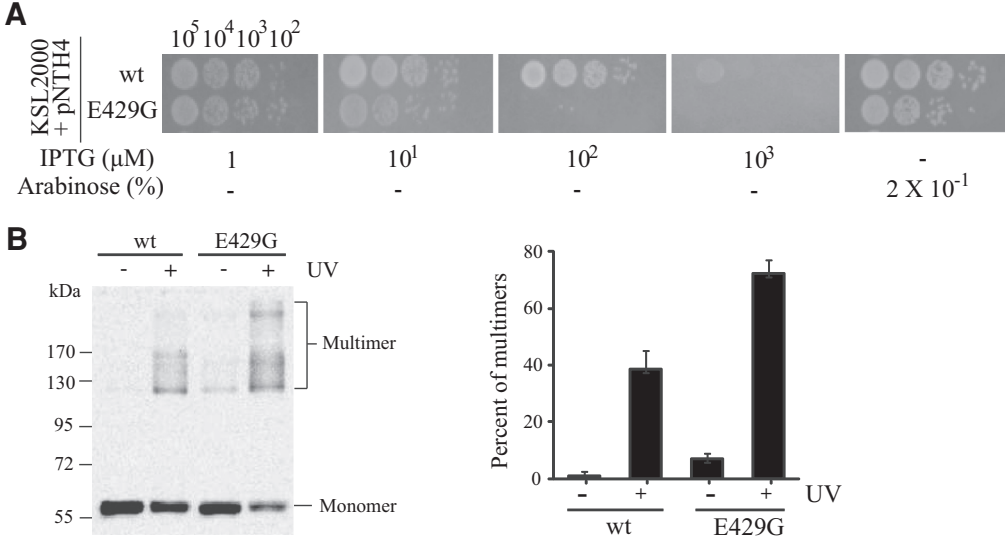

C
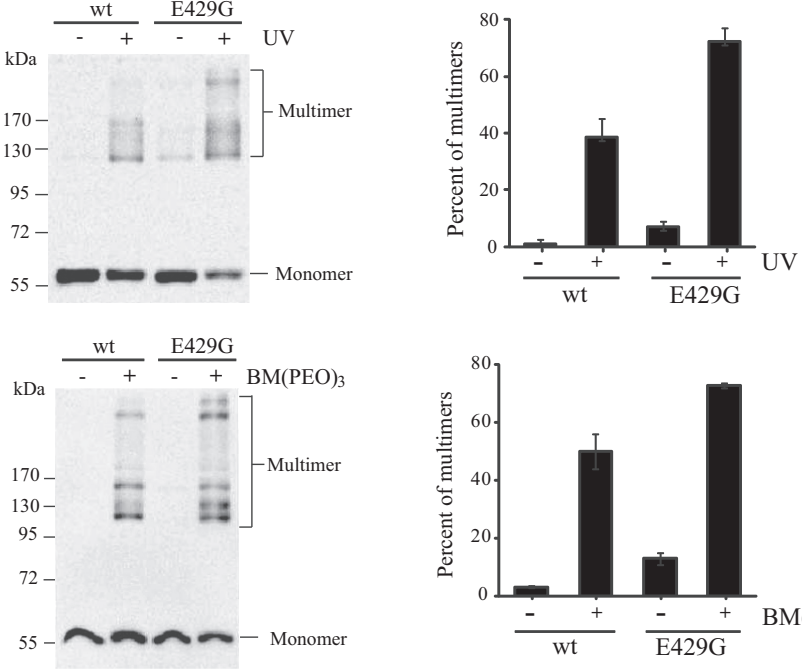

D

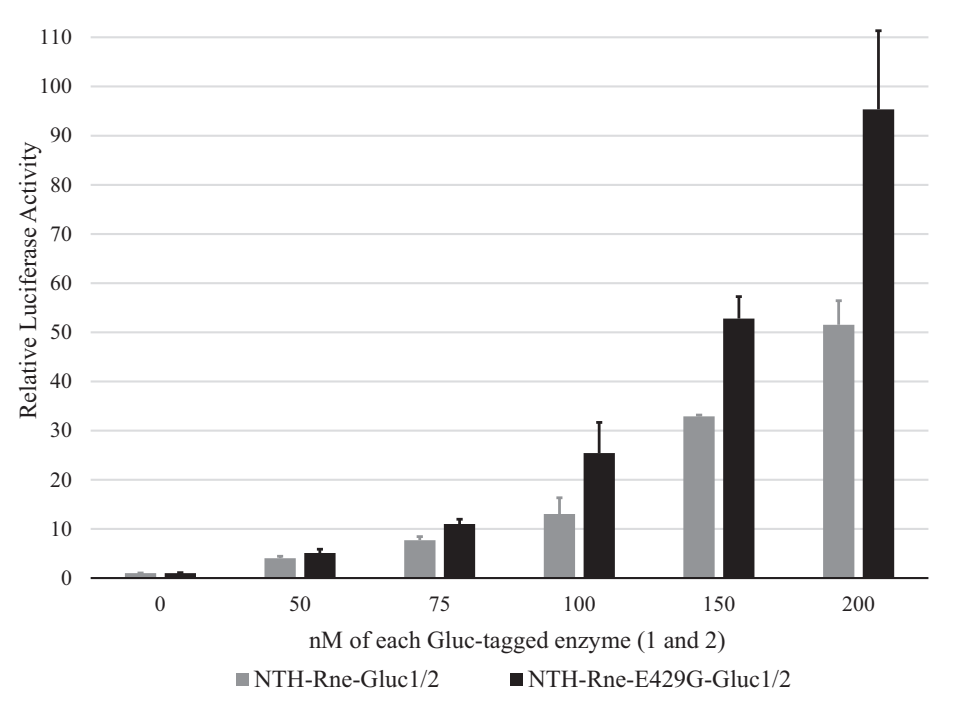

Figure 1. Growth characterization of E. coli cells expressing NTH-Rne-E429G and the multimerization efficiencies of NTH-Rne-wt and NTH-Rne-E429G. (A) Growth characteristics of KSL2000 cells, which are rne, expressing NTH-Rne-wt or NTH-RneE429G from pNTH4 plasmids. pNTH4 and pNTH4E429G were tested for their ability to support the growth of KSL2000 cells on LB-agar plates containing 1-1000 $\mu \mathrm{M}$ IPTG, while full-length RNase E was expressed from $\mathrm{pBAD}-\mathrm{RNE}$ with $0.2 \% \mathrm{~L}$-ara. The numbers $\left(10^{5}-10^{2}\right)$ above the figure represent the approximate number of viable cells present in each spot. (B) UV cross-linking of NTH-Rne and NTHRne-E429G. Purified NTH-Rne and NTH-RneE429G proteins were UV cross-linked for $20 \mathrm{~min}$. (C) Chemical cross-linking of NTH-Rne and NTHRne-E429G. Purified NTH-Rne and NTH-RneE429G proteins were chemically cross-linked for 30 min using $\mathrm{BM}(\mathrm{PEO})_{3}$. Cross-linked proteins were analyzed by Western blotting with anti-Rne monoclonal antibody. The cross-linking experiments were repeated three times and averaged. The error bars (standard errors of the mean) indicate the range of luciferase assay results. $(D)$ We mixed $100 \mathrm{nM}$ (50 nM Gluc1 + 50 $\mathrm{nM}$ Gluc2), $150 \mathrm{nM}$ (75 nM Gluc1 + $75 \mathrm{nM}$ Gluc2), $200 \mathrm{nM}$ (100 nM Gluc1 + $100 \mathrm{nM}$ Gluc2), $300 \mathrm{nM}$ (150 nM Gluc1 + $150 \mathrm{nM}$ Gluc2), and $400 \mathrm{nM}$ (200 nM Gluc1 + 200 nM Gluc2) of fusions of either wildtype or E429G mutant NTH-Rne proteins in binding buffer (20 mM Tris-Cl at pH 8.0, $100 \mathrm{mM} \mathrm{NaCl}, 50$ mM EDTA, $0.1 \mathrm{mM}$ DTT). Coelenterazine Native $(1 \times$; NanoLight Technology) was added and luciferase activity was detected by Tecan. Each data point was normalized with a data point of $0 \mathrm{nM}$. the two rne monomers (Fig. 2C). If this notion is correct, mutation of the glutamic acid at position 429 to aspartic acid (D), a residue that is smaller in size but identical in charge to glutamic acid, would be anticipated to increase the distance between negative charges at positions 429 and 272 and consequently diminish electrostatic charge repulsion between enzyme protomers (Fig. 2D). Similarly, mutation of glutamic acid at position 429 to a positively charged amino acid of the same approximate size (e.g., lysine $[\mathrm{K}])$ could increase electrostatic bonding with the glutamic acid residue at position 272 (Fig. 2E). Thus, E-to-D and E-to-K mutations would, like the E-to-G mutation, be anticipated to increase inter-molecular interaction and, consequently, ribonucleolytic activity of the mutant enzymes relative to wild-type Rne, with $\mathrm{E}$ to $\mathrm{K}$ having the greatest effect of the three mutations.

To test the notion that the charge and size of the amino acid residue at position 429 of Rne protomers can affect multimer formation, we tested the effects of different mutations at this position. Consistent with our hypothesis, we found that KSL2000 cells expressing NTH-RneE429D induced by various concentrations of IPTG had growth characteristics that were intermediate between those observed in cells expressing the wild-type NTHRne and those expressing NTH-Rne-E429G, whereas similarly induced expression of NTH-Rne-E429K showed greater inhibition of cell growth than was observed for NTH-Rne-E429G (Fig. 3A). In vitro analysis of the effects 


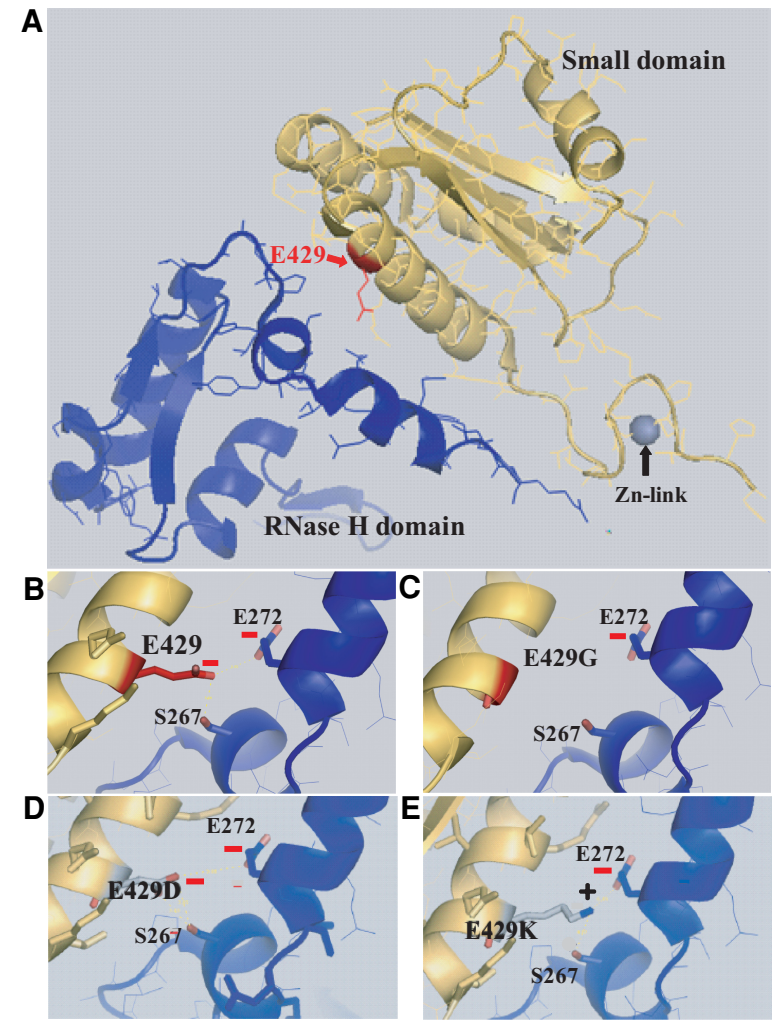

Figure 2. Structural simulations of NTH-Rne. $(A)$ Crystal structure of the local regions of the dimer in close proximity to E429. Crystal structure of the NTH-Rne tetramer (Protein Data Bank ID: 2COB) was modeled by PyMol (http://www.pymol.org). The protomer A is in gold, containing the E429 amino acid residue in red and the coordinated zinc ion in gray. The protomer $\mathrm{B}$ is in blue. $(B)$ Detailed picture of E429 and nearby amino acids E272 and S267 with ionic charges. (C) Mutation E429G modeled into the crystal structure, and the associated loss of charge. $(D)$ Mutation E429D modeled into the crystal structure, and the associated ionic charges. (E) Mutation E429K modeled into the crystal structure, and the associated ionic charges.

of the mutations on NTH-Rne crosslinking provided biochemical evidence supporting our interpretation of these cell growth data: The fraction of NTH-Rne protein present as higher-order structures increased as the characteristics of the 429 locus changed from wild type (negative charge) to E429D (negative charge but reduced proximity), to E429G (neutral), to E429K (positive charge) (Fig. 3B,C). Analogous amino acid substitutions intended to produce charge alterations at E272 were also constructed, but these mutations resulted in a sharp reduction of enzyme activity, making study of their effects impractical.

Altered enzyme activity resulting from mutations in the NTH-Rne-E429 residue is dependent on substrate length

In vitro testing of the ribonucleolytic effects of mutation of the E429 site of NTH-Rne using triphosphorylated ppp-RNA I as a substrate, or using triphosphorylated ppp-p23 RNA, a truncated form of M1 (the RNA compo- nent of the ribozyme RNase P) as a substrate, showed effects that correspond to those observed in vivo (Fig. 4A, B). However, to our surprise, cleavage of two other RNase E substrates, two short synthetic RNAs p-BR13 (McDowall et al. 1995) and p-23-13 (this study), which contain the sequences targeted in RNA I and p23 and are cut at sites identical to those cleaved in RNA I and p23, respectively, showed no detectable effects of the mutations (Fig. 4C,D).

A synthetic oligoribonucleotide (i.e., p-BR30) comprised of three repeated sets of the 10-nt RNase E cleavage sequence of p-BR13 (Feng et al. 2002) and which when cut by either the E429 or E429G enzymes generates cleavage products characteristic of the quasiprocessive mode of action reported previously (Feng et al. 2002), was also cut by the E429 and E429G enzymes at approximately the same rate (Fig. 5A), as was a short (47-nt) RNA designed to contain the target site and secondary structure believed to direct RNase E cleavage of the 108-nt RNA I (p-BR10 + hpT) (Fig. 5B).

Unlike ppp-RNA I and ppp-p23 RNA, which are substrates that when synthesized by in vitro transcription have $5^{\prime}$ triphosphate termini, p-BR13, p-23-13, p-BR30, and $\mathrm{p}-\mathrm{BR} 10+\mathrm{hpT}$ have $5^{\prime}$ monophosphate termini. To learn whether triphosphorylation of the $5^{\prime}$ terminus of a substrate is necessary for the E429G mutation to affect RNA cleavage, we replaced the triphosphoryl group at the $5^{\prime}$ end of RNA I with a monophosphate group. As seen in Figure 5C, such replacement had no effect on the differential activities of the E429 and E429G enzymes on cleavage of RNA I.

\section{The E429G mutation does not affect the RNA binding affinity of NTH-Rne}

We used an electrophoretic mobility shift assay (EMSA) to determine whether the E429G mutation enhances substrate binding. The RNA binding affinity of NTH-RneE429G to ppp-RNA I $\left(\mathrm{K}_{\mathrm{d}}=13.83 \mu \mathrm{M}\right)$ and ppp-p23 $(6.08$ $\mu \mathrm{M})$ was similar to that of NTH-Rne-wt $\left(\mathrm{K}_{\mathrm{d}}=12.08 \mu \mathrm{M}\right.$ and $6.15 \mu \mathrm{M}$, respectively) (Fig. 6A,B).

\section{Amidase $C$ is a trans-acting E. coli protein that up- regulates $R$ Nase $E$ activity in vivo}

RNase E activity can be modulated in trans, and E. coli proteins that inhibit RNase $E$ activity have been identified (Lee et al. 2003; Gao et al. 2006). Using a variant of the phenotypic hyperactivity selection strategy described in Figure 1, we discovered that the Amidase C protein, which is one of a large family of peptidoglycan hydrolase enzymes that carry out the hydrolysis of carbon-nitrogen bonds, has effects on Rne multimerization that are similar to those conferred by the E429G mutation. The AmiC protein previously has been found to be localized to the cell wall and to be implicated in cell division and cell wall rearrangement (Vermassen et al. 2019).

Direct confirmation that the amiC gene is a positive regulator of RNase E activity in vivo was obtained by assaying RNase E cleavage of the rne mRNA 5' UTR 

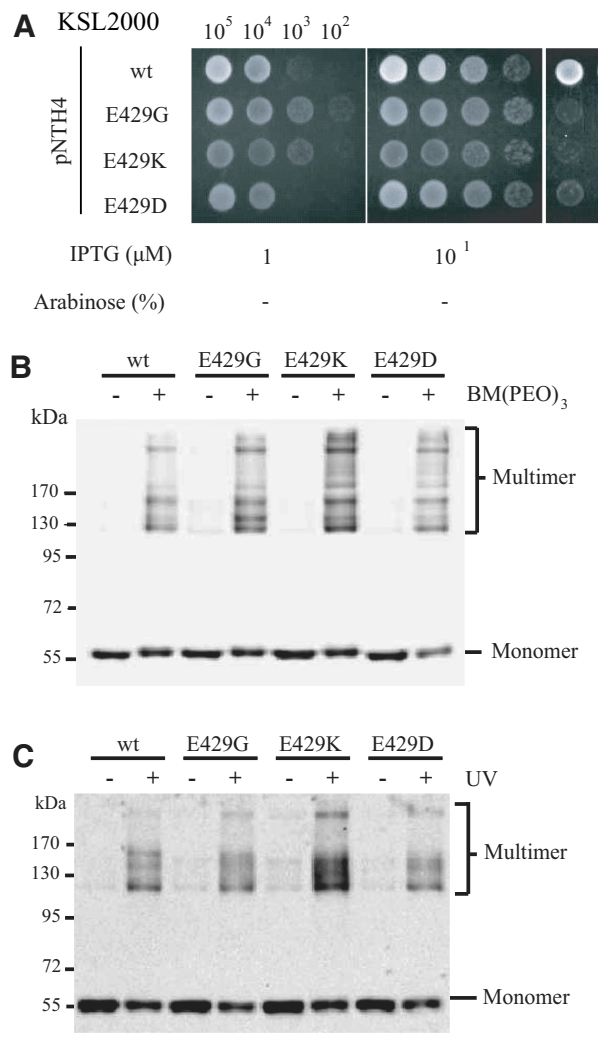

Figure 3. Effects of mutations of E429 on growth of $E$. coli cells and multimerization efficiencies of NTH-Rne in vitro. (A) Growth characteristics of KSL2000 cells expressing NTH-Rne-wt or NTH-Rne containing E429G, E429K, or E429D were analyzed using the same procedure described in the Materials and Methods. $(B, C)$ Purified NTH-Rne and NTH-Rne containing E429G, E429K, or E429D proteins were chemically cross-linked for 30 min using $\mathrm{BM}(\mathrm{PEO})_{3}(B)$ or UV crosslinked for $20 \mathrm{~min} .(C)$. Cross-linked proteins were analyzed by Western blotting with anti-Rne monoclonal antibody. autoregulatory region fused to the $1 a c Z$ reporter gene (Sousa et al. 2001). Adventitious expression of amiC resulted in a time-dependent and dose-dependent decrease in induced $\beta$-galactosidase production by the fusion construct (Fig. 7A,B). Conversely, deletion of amiC from wild-type cells was associated with decreased RNase E activity, as measured by accumulation of a constitutively produced RNase E target, the 5S rRNA precursor (Fig. 7C; Ray et al. 1982).

Amidase C interaction with both full-length Rne and NTH-Rne was shown by introducing a plasmid expressing hexahistidine-tagged AmiC into cells expressing either full-length Rne or NTH-Rne and using Ni-NTA resin to capture AmiC as described in the Materials and Methods. Both full-length RNase E and NTH-Rne were identified by Western blotting of eluates from cells expressing hexahistidine-tagged AmiC (Fig. 7D,E).

\section{Effects of Amidase C on RNase E in vitro}

AmiC protein was purified and tested for its ability to increase the activity of NTH-Rne in vitro using ppp-RNA I as a substrate (Fig. 8A). Whereas AmiC alone had no detectable ribonucleolytic activity (Fig. 8A-C), its presence stimulated cleavage of ppp-RNA I by NTH-Rne in a concentration-dependent manner (Fig. 8B). However, as had been observed for the E429G mutation, AmiC-mediated enhancement of NTH-Rne activity was not evident using p-BR13 as a substrate (Fig. 8C), leading us to investigate whether, like the effect of mutation at position 429 of
NTH-Rne, the effect of AmiC was associated with a change in the ratio of NTH-Rne multimers to monomers.

We used the split-luciferase assay described above (Remy and Michnick 2006) to learn whether substrate-dependent enhancement of RNase E activity by AmiC is associated with increased interaction between NTH-Rne-monomers. The results, shown in Figure 9A, indicate that incubation of NTH-Rne protein with purified AmiC protein generated a dose-dependent increase in luminescence, consistent with an increase in monomer-monomer interaction. We then tested whether AmiC affects RNase E activity in vitro in the absence of a $\mathrm{Zn}$ link and "small domain" protein segment that crystallographic studies have indicated is necessary for multimer formation (Callaghan et al. 2005a,b), using the NTH-Rne variant Rne-395, which lacks that segment (Caruthers et al. 2006). As seen in Figure 9B, no effect of AmiC on the activity of Rne-395 cleavage of ppp-RNA I was observed, suggesting that the Rne segment deleted in the Rne-395 construct is necessary for the AmiC-mediated increase in the activity of the enzyme.

\section{Discussion}

RNase E is a broadly active site-specific ribonuclease that degrades or processes a large variety of primary transcripts and also attacks degradation products that it or other ribonucleases generate (for recent reviews, see Carpousis et al. 2009; Mackie 2013; Bandyra and Luisi 2018). Earlier work has shown that its actions are dynamically controlled in vivo by a variety of mechanisms that include cleavage of 
A

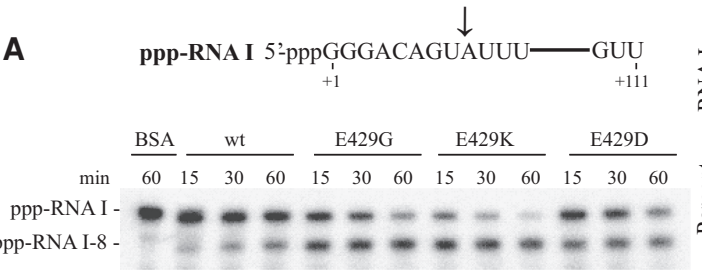

$\downarrow$

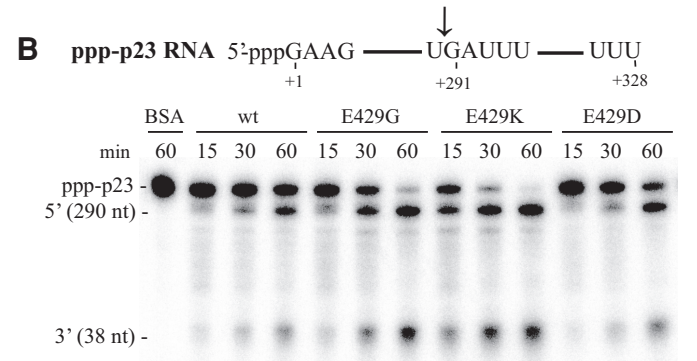

C $\quad$ p-BR13 5 '-pgGGACAGUAUUUG

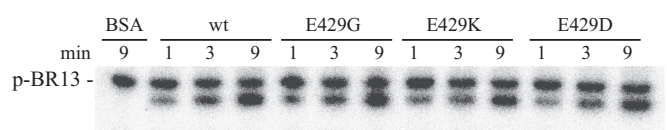

D

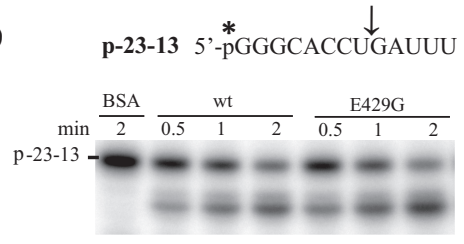

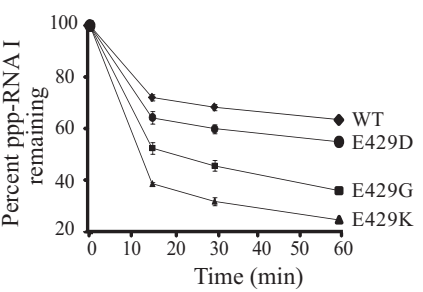
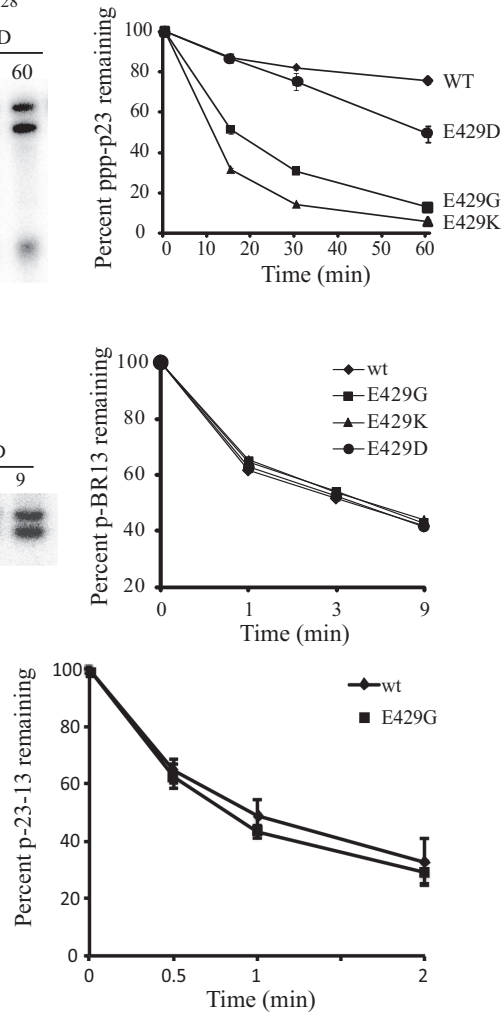

Figure 4. Effect of NTH-Rne and E429 locus variations on RNA catalysis. Ribonucleolytic activity of NTH-Rne-wt or NTHRne containing E429G, E429K, or E429D on ppp-RNA I $(A)$ and ppp-p23 RNA $(B)$ in vitro. Half of a picomole of uniformly labeled ppp-RNA I $(A)$ or uniformly labeled ppp-p23 RNA $(B)$ was incubated with 0.5 $\mu \mathrm{g}$ of purified NTH-Rne-wt or NTH-Rne containing E429G, E429K, or E429D in 30 $\mu \mathrm{L}$ of $1 \times$ cleavage buffer at $37^{\circ} \mathrm{C}$. Both substrates used in these experiments were synthesized in vitro as primary transcripts and contain $5^{\prime}$ triphosphorylated termini (LinChao and Cohen 1991; Kim et al. 1996), as indicated by their "ppp-" prefixes. Ribonucleolytic activity of NTH-Rne and E429G locus variations on oligomeric substrates in vitro $(C, D)$. Half a picomole of $5^{\prime}$ end-labeled p-BR13 $(C)$ or $5^{\prime}$ end-labeled p-23-13 $(D)$ was incubated with $50 \mathrm{ng}$ of purified NTH-Rne-wt or E429 locus variations in $30 \mu \mathrm{L}$ of $1 \times$ cleavage buffer at $37^{\circ} \mathrm{C}$. The location of the ${ }^{32} \mathrm{P}$-labeled phosphate in monophosphorylated (as indicated by the "p-" prefix) p-BR13 and p-23-13 is indicated with an asterisk, and the RNase E cleavage site is indicated with an arrow. its own mRNA (Jain and Belasco 1995), the sequence and structural features of substrates (Lin-Chao et al. 1994; McDowall et al. 1995; Mackie 1998), and cellular proteins that bind to RNase $\mathrm{E}$ and interfere with its ribonucleolytic activity (Lee et al. 2003; Gao et al. 2006; Singh et al. 2009; Göpel et al. 2013). It has long been known that RNase E, which when purified from cells is de facto at high concentrations, exists in multimeric forms /Callaghan et al. 2005b), and crystallographic studies of purified RNase E have revealed a homotetrameric structure consisting of dimerized dimers of the Rne peptide (Callaghan et al. 2005a). The investigations reported here reveal the extent of multimerization of RNase $\mathrm{E}$ as a mechanism for control of the catalytic activity of RNase E differentially on different substrates. We have shown that RNase E catalytic activity can be altered by Rne mutations and by at least one other protein that affects the quaternary structure of the enzyme and that the effects of such alterations of cleavage activity are not uniform among substrates.

Based on crystal structure analysis of NTH-Rne, the loss of negative charge in the E429G mutation, and the three-dimensional proximity of the E429 locus to a nega- tively charged amino acid on the complementing protomer, we hypothesized that amino acid substitutions at this locus can affect the extent of ionic interference between the negatively charged loci and would differentially alter the ability of RNase E protomers to interact with each other when forming higher-order structures. This notion was supported by evidence showing that amino acid substitutions that changed the electrostatic charge from negative to either neutral or positive at the 429 site, or that increased the distance between the negative charges of the two interacting protomers, resulted in increased enzyme multimerization. These effects were independent of the presence of substrate.

Structural analysis of NTH-Rne and the sites of interaction between the enzyme and its substrate(s) has in some instances yielded inferences that have not been supported by results of biochemical experiments. For example, crystallographic data have suggested that dimerization of protomers is required for the enzyme to bind to and cleave substrates (Callaghan et al. 2005b), whereas truncated forms of the enzyme that lack regions that the crystallographic analysis has suggested are necessary for such 
A p-BR30 5'-pACAGUAUUUGACAGUAUUUGACAGUAUUUG
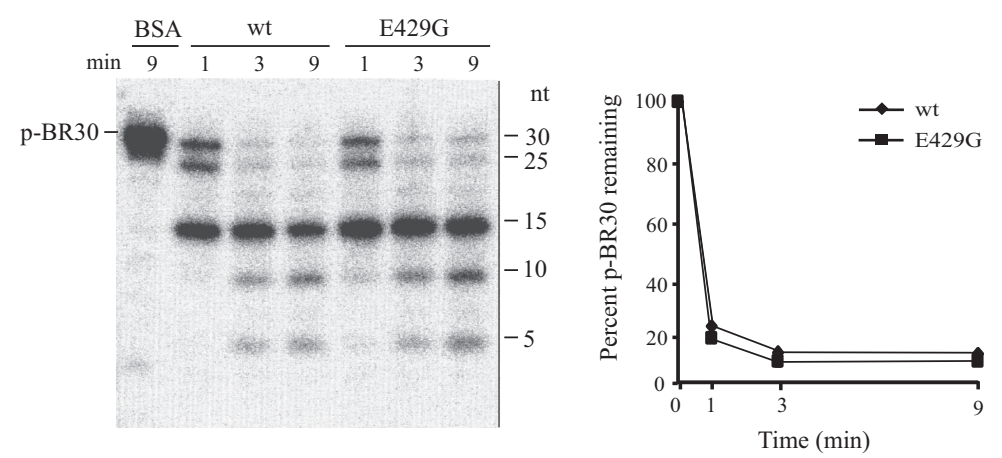

B

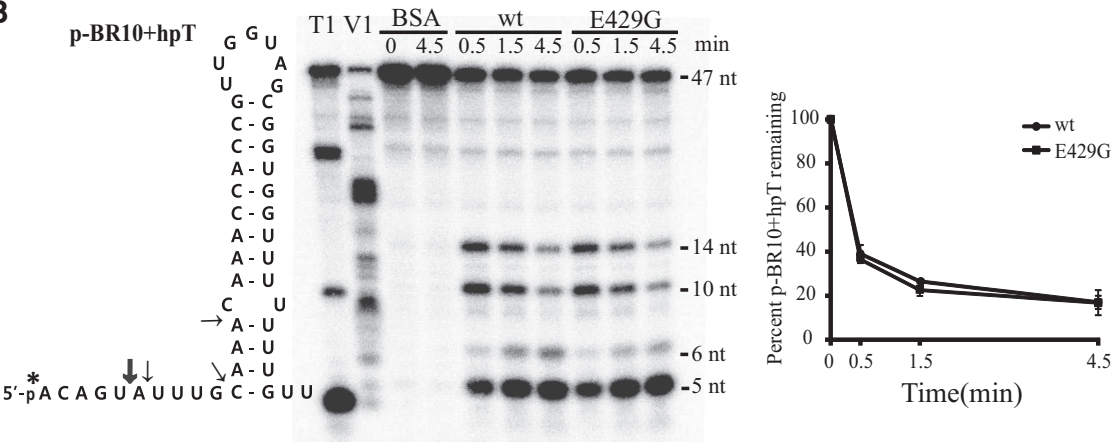

C

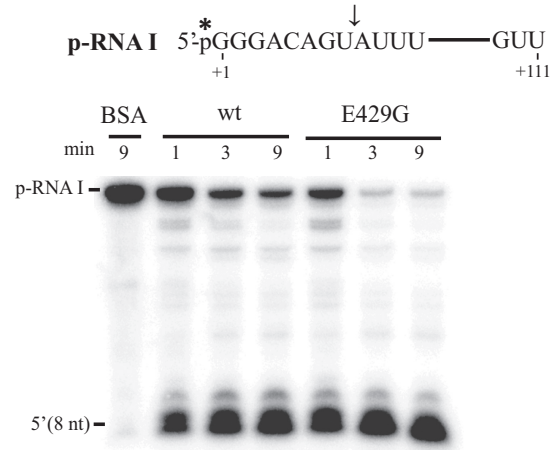

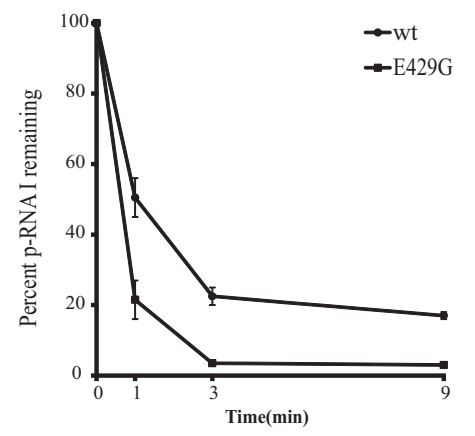

Figure 5. Ribonucleolytic activity of NTH-Rne and NTH-Rne-E429G on RNA I derived substrates. (A) Cleavage of $5^{\prime}$ end-labeled p-BR30 substrate. The RNase E cleavage sites and adventitious cleavage sites are indicated with bold and regular arrows, respectively. $(B)$ The predicted secondary structure of $\mathrm{p}-\mathrm{BR} 10+\mathrm{hpT}$ RNA substrate and in vitro cleavage of $5^{\prime}$ monophosphorylated p-BR10+hpT RNA substrate by NTH-Rne-wt or NTH-Rne-E429G. The secondary structure was deduced using the $\mathrm{M}$-fold program and RNase $\mathrm{T} 1$ and V1 digestion. Major (5-nt) and minor (6-, 10-, and 14-nt) RNase E cleavage sites are indicated with bold and regular arrows, respectively. One picomole of $5^{\prime}$ end-labeled p$\mathrm{BR} 10+\mathrm{hpT}$ was incubated with $50 \mathrm{ng}$ of purified NTH-Rne-wt or NTH-Rne-E429G in $12 \mu \mathrm{L}$ of $1 \times$ cleavage buffer at $37^{\circ} \mathrm{C}$. $(C)$ Cleavage of $5^{\prime}$ end-labeled, monophosphorylated p-RNA I substrate. Two picomoles of $5^{\prime}$ end-labeled p-RNA I were incubated with $50 \mathrm{ng}$ of purified NTHRne-wt or NTH-Rne-E429G. The RNase E cleavage site is indicated with an arrow. dimerization are nevertheless enzymatically functional, albeit with lower specific activity than structures that include these domains (Caruthers et al. 2006; Anupama et al. 2011; Kim et al. 2016; Baek et al. 2019). Such observations may perhaps reflect an ability of these enzyme protomers, which still retain their $5^{\prime}$ end RNA-binding "pocket," to form "pseudodimers" on RNA substrates by recapitulating the canonical dimer interaction using RNA as a scaffold, as suggested by Ali and Gowrishankar (2020), or through an undetermined interaction(s) involving other mechanisms or loci.

Our finding that the effects of multimerization on the specific activity of RNase E do not occur uniformly among substrates raises the prospect that multimerization may be relevant to regulation of relative rates of cleavage of different substrates in vivo. In our experiments, increased multimerization was associated with enhancement of the enzyme's ability to cleave two RNase E substrates
$>100 \mathrm{nt}$ in length but did not enhance cleavage of short oligomers that contain the same cleaved sequence. This finding, coupled with the fact that stimulation of cleavage via enhanced multimerization by mutation of the 429 site is independent of the extent of phosphorylation of the $5^{\prime}$ terminus (Fig. 5C), suggests a model in which longer RNAs may bind concurrently to separate dimers, either within the same tetramer or between proximate tetramers. According to this model, higher-order quaternary structures may facilitate interaction of a long substrate with both the protomer subunit carrying out disruption of a phosphodiester bond and a second protomer that is a component of the same multimer but is not the dimer partner of the one doing the cleavage. A corollary of this notion is that short RNA decay intermediates, whose $5^{\prime}$ monophosphate ends enhance further attack by RNase E (Mackie 1998; Jiang and Belasco 2004; Garrey et al. 2009; Jourdan et al. 2010; Go et al. 2011), may be cleaved 
A

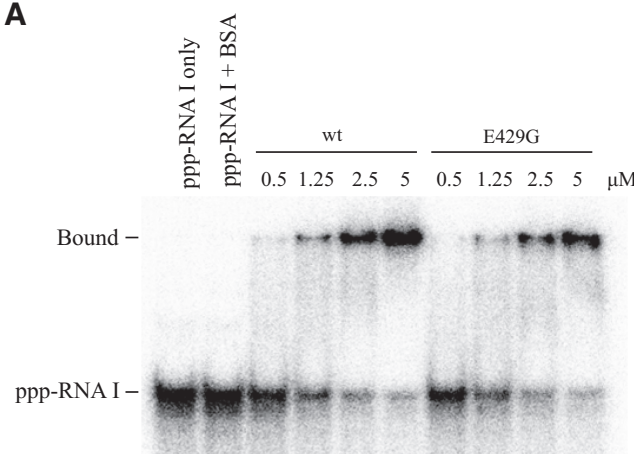

B

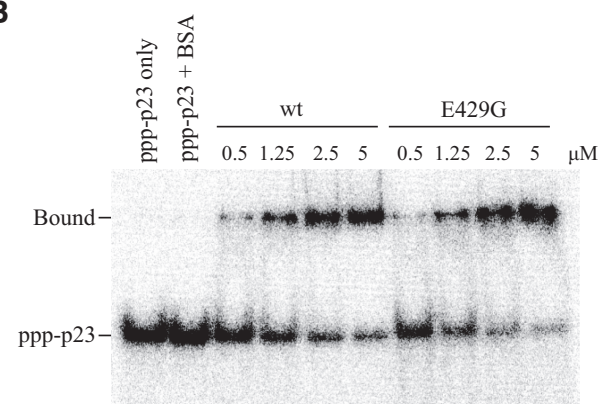

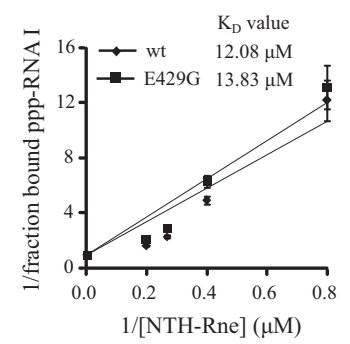

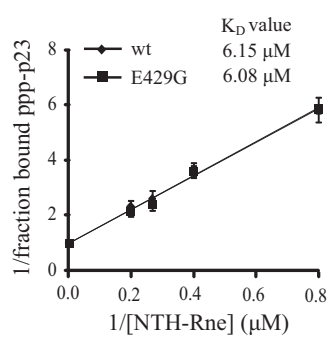

Figure 6. Effects of E429G on RNA binding affinity to ppp-RNA I and ppp-p23 RNA. One picomole of uniformly labeled ppp-RNA I $(A)$ or ppp-p23 RNA $(B)$ was incubated with increasing amounts of purified NTHRne or NTH-Rne-E429G proteins in $20 \mu \mathrm{L}$ of EMSA buffer and analyzed using $8 \%$ PAGE. Increasing concentrations of the proteins $(0.5-5 \mu \mathrm{M})$ were used. Binding constants were calculated based on slopes calculated from the graphs in the right panel. efficiently by the combined action of protomer components of the same dimer, whereas primary transcripts, which generally are $>100 \mathrm{nt}$ and have $5^{\prime}$ triphosphate ends that reduce their binding to the enzyme (Go et al. 2011), would be cleaved poorly by protomer components of individual dimers. In this regard, it is worth noting that a recent study has suggested that cleavage by tetrameric RNase E is affected by the distance of the cleavage site from the $5^{\prime}$ end of the cleaved RNA (Baek et al. 2019).

Alignment of the amino acid sequences of the related enzyme, RNase G, with NTH-Rne (Clustal Omega) (McWilliam et al. 2013), shows that the E272 amino acid residue is among the residues conserved in both enzymes, whereas the amino acid residue at the 429 location is not conserved. The E429 residue in NTH-Rne corresponds to a positively charged arginine in RNase G, which maintains a level of multimerization that is both higher than that of RNase E and consistent across enzyme concentrations (Jiang and Belasco 2004).

Alignment (Clustal Omega) (McWilliam et al. 2013) of sequences culled from GenBank (Benson et al. 2013) using BLAST (Altschul et al. 1990) indicates that the glutamic acid at position 429 is highly conserved among RNase E homologs, as is E272, the residue in the RNase H domain that is in close proximity to E429. Such conservation suggests a possible selective biological benefit from the occurrence of these two residues in positions that facilitate their interaction. The discovery that multimerization differentially affects the ability of RNase E to cleave different substrates argues that the ability to dynamically regulate the extent of multimerization and consequently the relative rates of cleavage of different substrates may have a previously unsuspected physiological benefit. The further discovery that a separate E. coli protein, AmiC, can regulate the extent of RNase E multimerization is consistent with this notion and raises the prospect that functional enhancement of RNase E activity, via alteration of its multimerization rather than its expression level, may have evolved as a method of dynamically modulating RNase E activity either locally or temporally within the cell. In cells, RNase $\mathrm{E}$ is bound to the inner plasma membrane (Miczak et al. 1991; Liou et al. 2001; Khemici et al. 2008), whereas AmiC is located both within the cytoplasm and the periplasmic space (Bernhardt and de Boer 2003; Ize et al. 2003; Sikdar and Doerrler 2010). The differential ability to cleave long versus short RNAs may benefit cells under particular environmental conditions. Investigation of events and mechanisms that could dynamically regulate this balance may yield additional insights about modulation of cellular RNase E activity at the level of quaternary structure.

\section{Materials and methods}

\section{Bacterial strains and plasmids}

The strains and plasmids used in this study are listed in Supplemental Table S1. None of the plasmid constructs containing NTH-Rne, any of its three mutations at amino acid position 429 , or its fusions with Gluc 1 and 2 contained the autoregulatory 5' UTR sequence present in the endogenous rne gene. To construct pNTH4 containing random mutations in the small domain, the region encoding Rne amino acids 382-529 was amplified using primers rne-1146F (5'-TGGCCTGCTGGAAA TGTC-3') and 529-hisR (5'-ACGTCTAGACTAGTGGTGG TGGTGGTGGTGCAGCGCAGGTGTTCCGGACG-3') in the 


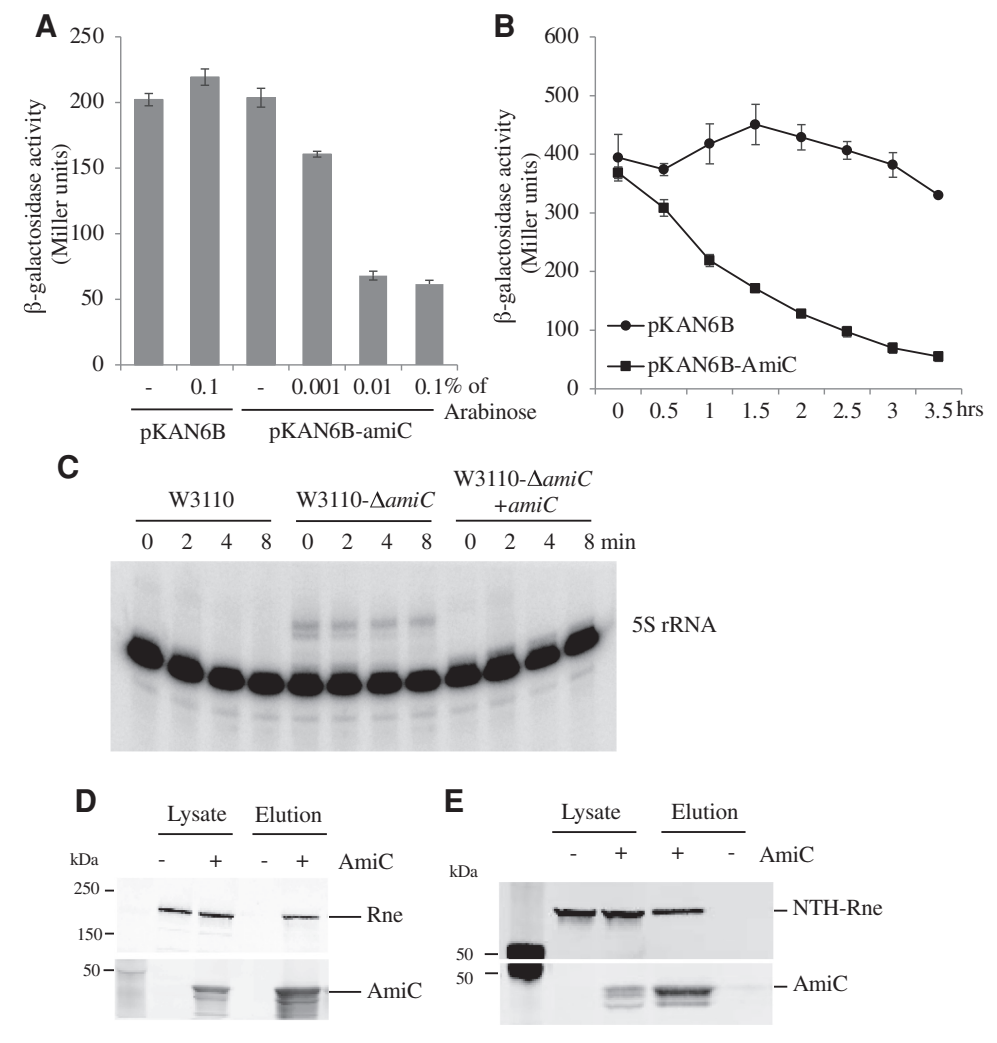

Figure 7. Effects of AmiC on RNase E and NTH-Rne activity in vivo. (A) $\beta$-Galactosidase activity (in Miller units) expressed from a chromosomal rneE:lacZ fusion. Cells transformed with pKAN6B and pKAN6B-amiC were grown in $\mathrm{LB}$, and the expression of $\mathrm{AmiC}$ was induced at an $\mathrm{A} 600 \sim 0.2$ by different concentrations of arabinose. The cells were assayed for $\beta$-galactosidase activity $1.5 \mathrm{~h}$ after induction. $(B)$ The same cells as in $A$ were grown in LB, and the expression of $\mathrm{AmiC}$ was induced at an $\mathrm{A} 600 \sim 0.2$ by $0.1 \%$ of arabinose and cells were assayed for $\beta$-galactosidase activity every $30 \mathrm{~min}$. $(C)$ The maturation of precursor $5 \mathrm{~S}$ rRNA in amiC-deleted cells. A deletion mutant of Amidase $\mathrm{C}$ was created in the W3110 background, W3110- $\triangle a m i C$, which was then complemented with exogenous AmiC by transformation with the arabinose-inducible pKAN-amiC plasmid. Ten micrograms of total RNA was separated by a $6 \%$ polyacrilamide gel, blotted, and probed with the $5 \mathrm{~S}$ probe. $(D, E)$ Ligand fishing of Rne $(D)$ and NTH-Rne $(E)$ with 6x-His-AmiC. Proteins coeluted using Ni-NTA resin were analyzed by Western blot and probed with either antiRNE or antiHIS antibodies. presence of $0.1 \mathrm{mM} \mathrm{MnCl}$. Amplified DNA fragments were digested with DraIII and XbaI and ligated into pNRNE4. Mutants were isolated as described previously (Shin et al. 2008).

To construct pNTH4-E429K, PCR site-directed mutagenesis was performed using primers E429K-F (5'-TCTATTCTGCG TCTGATCGAAAAAGAAGCGCTG-3') and Nrne-529R (5'-TC TAGAGTGGTGGTGGTGGTGGTGCAGCGCAGGTTGTTCC GGACG-3'). To construct pNTH4-E429D, PCR site-directed mutagenesis was performed using primers E429D-F (5'-TCTAT TCTGCGTCTGATCGAAGATGAAGCGCTG-3') and Nrne529R.

To construct the NTH-Rne and NTH-Rne-E429G split-luciferase subunit fusion proteins, we used recombinant PCR. An NTHRne or NTH-Rne-E429G DNA fragment containing the G-luciferase linker was made by PCR reaction using the NTH-RneNotI-F (CAGCGGCCGCAGGAGGTTACG) and NTH-Rne-GlucLink-R (GCCACCGCCACCATCGA TCAGCGCAGGTTGT TCCGG) primers using the pNTH4 or pNTH4-E429G plasmid as a template. This fragment was also used in producing pNTH4-Gluc2 and pNTH4-E429-Gluc2. The G-luciferase-1 DNA fragment containing the NTH-Rne or NTH-Rne-E429G sequence at the $\mathrm{N}$ terminus and $6 \times$ Histidine tag at the $\mathrm{C}$ terminus was made by PCR reaction using NTH-Rne-GlucLink-F (CC GGAACAACCTGCGCTGATCGATGGTGGCGGTGGC) and Gluc1-6H-XbaI-R (TAGAGGTCTAGATTAGTGGTGGTGGTG GTGGTGGCCTATGCCGCCCTGTGC) primers. The pGluc1 plasmid was used as a template. Two DNA fragments were combined using NTH-Rne-NotI-F and Gluc1-6H-XbaI-R primers. The recombinant PCR fragment was treated with NotI and XbaI and ligated into the pNTH4 plasmid, creating pNTH4-Gluc1 and pNTH4-E429G-Gluc1. For pNTH4-Gluc2, the G-luciferase-2 DNA fragment containing homologous sequences of NTH-Rne at the $\mathrm{N}$ terminus and a $6 \times$ Histidine tag at the $\mathrm{C}$ terminus was made by PCR reaction using NTH-Rne-GlucLink-F (CCGGAA
CAACCTGCGCTGATCGATGGTGGCGGTGGC) and Gluc26H-Xbal-R (TAGAGGTCTAGATTAGTGGTGGTGGTGGTG GTGGCCTATGCCGCCCTGTGC) primers. The pGluc2 plasmid was used as a template. The DNA fragments were combined using NTH-Rne-NotI-F and Gluc2-6H-XbaI-R primers. The recombinant PCR fragments were treated with NotI and XbaI and ligated into the pNTH4 plasmid, creating pNTH4-Gluc2 and pNTH4-E429G-Gluc2.

To construct a plasmid expressing the transcript BR $10+h p T$, the kanamycin resistance gene npt1 was cut from plasmid pUC4K by PstI and cloned into plasmid pUC19, generating pUC19K. A DNA region for BR10+hpT containing the RNA I promoter was PCR-amplified from plasmid pBR322 with primers pUC-BR10 + hpT-F (5'-ATGAATTCAGCCACTGGTAACAGGA TTAGCA- $\left.3^{\prime}\right)$ and RNAI-XbaI-R (5'-ATTCTAGAATCTCAT GACCAAAATCCCTTAAC-3'). The gel-purified PCR products were introduced into the EcoRI- and Xbal-cleaved plasmid pUC19K, resulting in pUC-BR10 + hpT.

To construct $\mathrm{pKAN} 6 \mathrm{~B}$-amiC, the amiC coding region was amplified from E. coli W3110 genomic DNA using amiC-F4 (TGCGGCCGCAATAATTTTGTTTAACTTTAAGGAGAGAA T TCATATGTCAGGATCCAACAC) and amiC-His-R (ATAG ATCTTCAGTGGTGGTGGTGGTGGTGTCCCCTTCTCGCC AGCGTC) primers. The amplified DNA fragment was treated with EcoRI and BglII and inserted into pKAN6B (Yeom et al. 2008).

The W3110- $\triangle a m i C, a m i C$ deletion strain was created in the $E$. coli W3110 strain using the one-step inactivation method (Datsenko and Wanner 2000). The entire amiC coding region was replaced with the chloramphenicol resistance gene. The AmiCpKD3-F (TAAAGTTTCCGG TCAAATTAGTCGTTTACTTGT TACACAGCTTAGGTGTAGGCTGGAGCTGCT) and AmiCpKD3-R (TTTGTTTCTGGTCTCCCATAAAAAAGCGCCATT CAGCGCCTTTTTACA TATGAATATCCTCCTTA) primers 
A

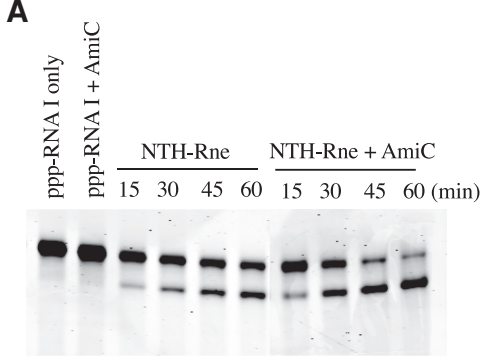

B

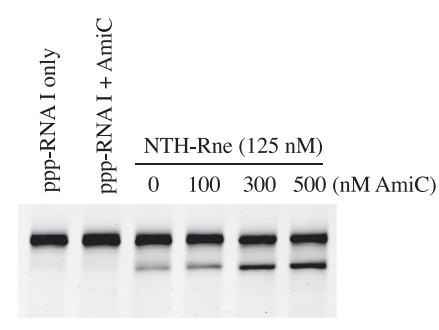

C

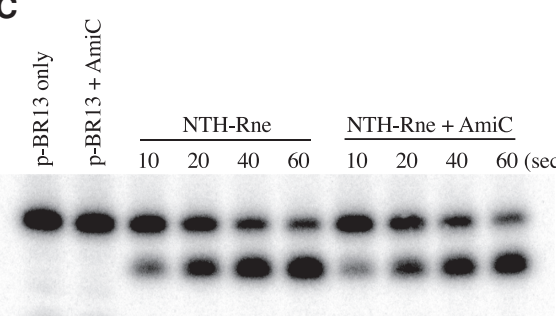

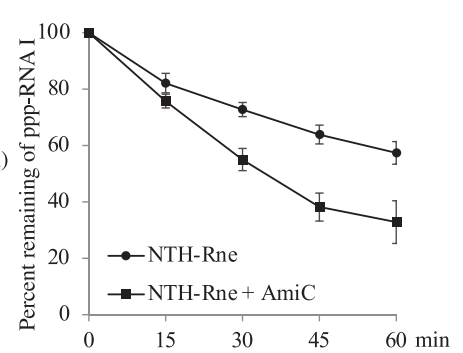
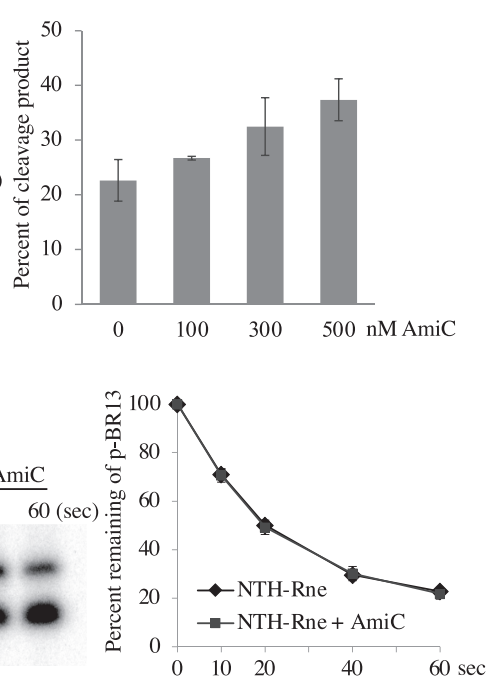

Figure 8. Effect of AmiC on ppp-RNA I and p-BR13 catalysis by NTH-Rne in vitro. (A) Cleavage of the pppRNA I substrate by NTH-Rne in the presence of AmiC. ppp-RNA I $(1 \mu \mathrm{M})$ was incubated with $25 \mathrm{nM}$ purified NTH-Rne or $25 \mathrm{nM}$ purified NTH-Rne with $100 \mathrm{nM}$ AmiC in $1 \times$ cleavage buffer at $37^{\circ} \mathrm{C} .(B)$ Cleavage of the ppp-RNA I substrate by NTH-Rne in the presence of different concentrations of AmiC in vitro. ppp-RNA I $(1 \mu \mathrm{M})$ was incubated with $125 \mathrm{nM}$ purified NTH-Rne and different concentrations of AmiC in 1× cleavage buffer for $5 \mathrm{~min}$ at $37^{\circ} \mathrm{C}$. The reaction mixtures were electrophoresed on an $8 \%$ polyacrylamide gel and visualized by staining with SYTO60 and scanning with Odyssey (LICOR). (C) Cleavage of the p-BR13 substrate by NTHRne in the presence of AmiC in vitro. Twenty picomoles of $5^{\prime}$ end-labeled p-BR 13 was incubated with $50 \mathrm{nM}$ purified NTH-Rne or $50 \mathrm{nM}$ purified NTH-Rne with $100 \mathrm{nM}$ AmiC in $1 \times$ cleavage buffer at $37^{\circ} \mathrm{C}$. The reaction mixtures were electrophoresed on an $8 \%$ polyacrylamide gel and visualized using a Typhoon scanner (GE Healthcare).

were used to amplify the FRT-chloramphenicol cassette from the pKD3 plasmid. The PCR product was treated with DpnI to remove template plasmid and transformed into W3110 by electroporation.

\section{Characterization of bacterial cell growth}

pNTH4-based plasmids containing random mutations in the $\mathrm{Zn}$ link and small domains were introduced into strain KSL2000, in which a chromosomal deletion in rne is complemented by a cloned copy of full-length rne expressed from an arabinose-inducible plasmid-borne gene (pBAD-RNE). KSL2000 cells carrying pNTH4 that were induced to express NTH-Rne by addition of $100 \mu \mathrm{M}$ IPTG to culture media grow normally when deprived of full-length RNase E by transfer of host bacteria to media lacking arabinose (Fig. 1A) but show retarded colony formation when excessive NTH-Rne protein is induced by addition of IPTG at a concentration of $1 \mathrm{mM}$ (Lee et al. 2002; Tamura et al. 2006). Cells producing hyperactive RNase $\mathrm{E}$ variants show retarded colony formation even when induced by $100 \mu \mathrm{M}$ IPTG (Claverie-Martin et al. 1991; Jain et al. 2002; Yeom and Lee 2006; Go et al. 2011). We screened a plasmid population mutagenized in the multimer-forming segment of RNase $\mathrm{E}$ for hyperactive-variant clones that have limited colony-forming ability at an IPTG concentration of $100 \mu \mathrm{M}$ but grow normally at inducer concentrations between 1 and $10 \mu \mathrm{M}$. From 3000 transformants tested, we obtained one clone that, in the presence of 1-10 $\mu$ M IPTG, showed colony-forming ability comparable with that seen with unmutagenized NTH-Rne in the presence of $100 \mu \mathrm{M}$ IPTG but reduced growth at $100 \mu \mathrm{M}$ IPTG (Fig. 1A).

Overnight cell cultures were diluted 1:100 into LB media containing antibiotics and $10 \mu \mathrm{M}$ IPTG. After incubation for $2 \mathrm{~h}$ at $37^{\circ} \mathrm{C}$, each sample was further diluted 1:10 into LB media contain- ing antibiotics and either $0.2 \%$ arabinose or $1,10,100$, or $1000 \mu \mathrm{M}$ IPTG. After incubation for $2 \mathrm{~h}$ at $37^{\circ} \mathrm{C}$, samples were serially diluted 1 to 1000 -fold into corresponding LB media and $10 \mu \mathrm{L}$ of each sample was spotted onto the designated plates. Additionally, we spread $50 \mu \mathrm{L}$ of a 1000 -fold dilution in LB media $+0.2 \%$ arabinose onto plates to determine the number of viable cells.

\section{Protein analysis}

Western blots for NTH-Rne were performed as previously described (Lee et al. 2002). Each protein band was quantitated using a ChemiDoc XRS+ system with Image Lab software (Bio-Rad). NTH-Rne-wt, NTH-Rne-E429G, NTH-Rne-E429K, and NTHRne-E429D proteins were purified from KSL2000 cells harboring pNTH4, pNTH4-E429G, pNTH4-E429K, and pNTH4-E429D, respectively, using Ni-NTA agarose (Qiagen). The cultures were grown to mid-log phase, induced with $100 \mu \mathrm{M}$ IPTG for $1.5 \mathrm{~h}$, and harvested. The cells were resuspended in lysis buffer ( $50 \mathrm{mM} \mathrm{NaH} \mathrm{PO}_{4}, 300 \mathrm{mM} \mathrm{NaCl}, 5 \mathrm{mM}$ imidazole at $\mathrm{pH} 8.0$ ) and opened three times by French Press at a pressure of 500 psi. The cell lysate was incubated for $1 \mathrm{~h}$ at $4^{\circ} \mathrm{C}$ with Ni-NTA agarose. When purifying proteins used for assaying multimerization, the cell lysate was treated with $100 \mu \mathrm{g} / \mathrm{mL}$ RNase A at this step to prevent nonspecific protein interaction via RNA molecules in the UV and chemical cross-linking assays. Protein purified for use in catalytic assays omitted the RNase A step. The protein-bound Ni-NTA agarose was washed with wash buffers (same as lysis buffer but variable imidazole concentration, 20, 40, 60, and 80 $\mathrm{mM})$. The protein was eluted from the resin using elution buffer (same as lysis buffer but $150 \mathrm{mM}$ imidazole). Purified protein was dialyzed into storage buffer $(50 \mathrm{mM}$ Tris- $\mathrm{HCl}$ at $\mathrm{pH} 7.5,500 \mathrm{mM}$ $\mathrm{NaCl}, 1 \mathrm{mM}$ EDTA, $1 \mathrm{mM}$ DTT, 30\% glycerol). The Bradford assay (Bradford reagent, Sigma-Aldrich B6916) was used to measure 


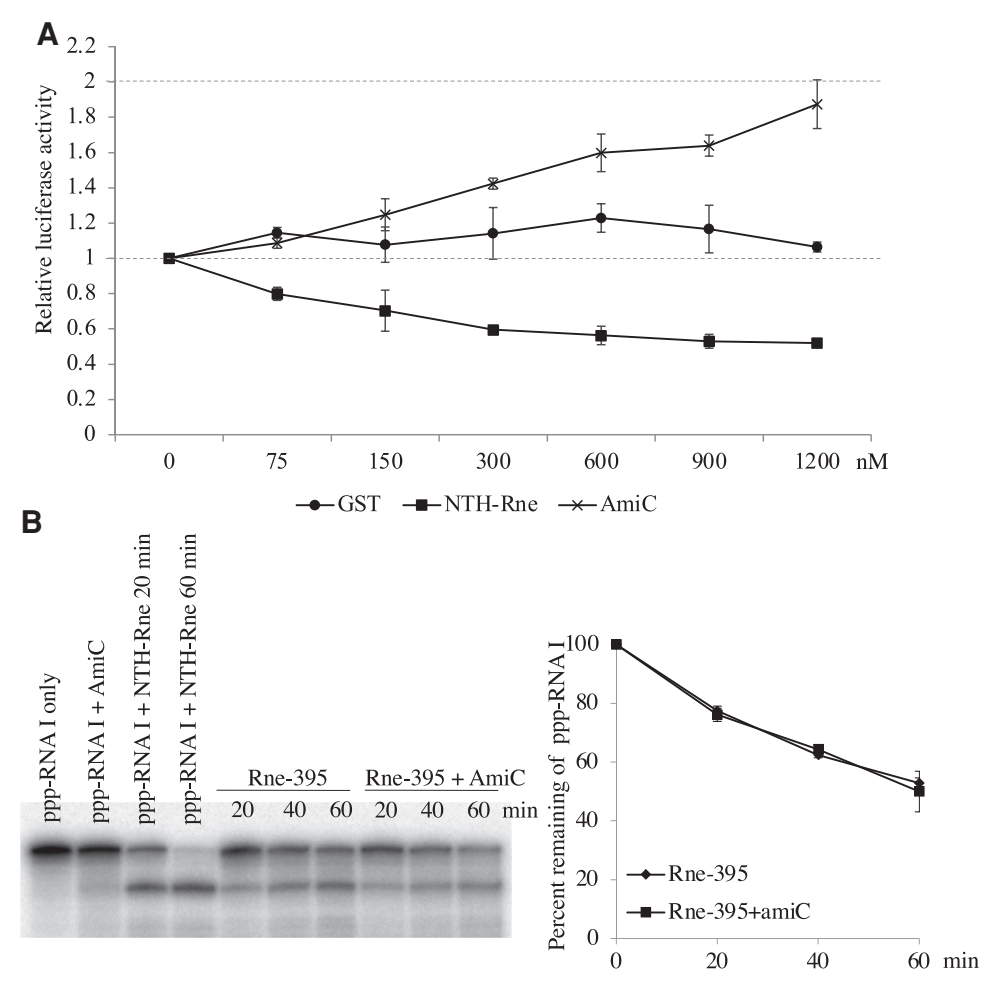

Figure 9. Effects of AmiC on NTH-Rne multimerization in vitro, immunoprecipitation analysis of AmiC interaction with full-length RNase E and NTH-Rne in vivo, and effects of AmiC on Rne-395 activity. (A) Luciferase assay. Purified NTH-Rne-Gluc1 and NTH-Rne-Gluc2 (both at $75 \mathrm{nM}$ ) were mixed with different concentrations of GST (a noninteracting protein control), NTH-Rne (unlabeled with Gluc), or AmiC proteins in binding buffer $(20 \mathrm{mM}$ Tris-Cl at $\mathrm{pH} 8.0,100 \mathrm{mM} \mathrm{NaCl}, 50 \mathrm{mM}$ EDTA, $0.1 \mathrm{mM}$ DTT), respectively. $1 \times$ Coelenterazine Native (NanoLight Technology) was added and luciferase activity was detected by Tecan. Subsequent analysis showed that the plasmids encoding NTH-Rne-Gluc1 and NTH-Rne-Gluc2 both carried a point mutation conferring a $\mathrm{C} 471 \mathrm{Y}$ missense mutation that was not present in those used to previously purify these proteins. There were no detectable effects of the mutation on any enzyme property that we tested. $(B)$ Universally labeled ppp-RNA I (100 nM) was incubated with $100 \mathrm{nM}$ purified NTH-Rne. Purified Rne-395 (1 $\mu \mathrm{M})$ was incubated with 1 $\mu \mathrm{M}$ AmiC in $1 \times$ cleavage buffer at $37^{\circ} \mathrm{C}$. The reaction mixtures were electrophoresed on an $8 \%$ RNA gel and visualized by Typhoon (GE Healthcare).

the concentrations of enzyme present in these preparations for calculation of concentrations used in in vitro analyses. To cross-link the subunits of NTH-Rne-wt, NTH-Rne-E429G, NTH-Rne-E429K, and NTH-Rne-E429D, 40 pmol of purified proteins in $40 \mu \mathrm{L}$ of storage buffer were exposed to UV light (254 nm) in a CL1000 ultraviolet cross-linker (UVP). Samples were removed after $20 \mathrm{~min}$ of incubation, mixed with an equal volume of protein loading buffer $(100 \mathrm{mM}$ Tris- $\mathrm{Cl}$ at $\mathrm{pH} 6.8,4 \%$ SDS, $0.2 \%$ bromophenol blue, $30 \%$ glycerol, $200 \mathrm{mM} \beta$-mercaptoethanol), and separated by $10 \%$ SDS-PAGE. Multimerization of the purified proteins was also analyzed using a cross-linking reagent, $\mathrm{BM}(\mathrm{PEO})_{3}$, as has been previously described for the analysis of RNase E/G multimeric forms (Jiang and Belasco 2004). For the measurement of Circular Dichroism (CD) spectroscopy, purified proteins were dialyzed in $\mathrm{CD}$ buffer $\left(20 \mathrm{mM} \mathrm{NaH}_{2} \mathrm{PO}_{4}\right.$ at $\mathrm{pH} 7.5$ and $200 \mathrm{mM} \mathrm{NaCl}$ ). Spectra were collected in the range of 340$200 \mathrm{~nm}$ at intervals of $1 \mathrm{~nm}$, with three accumulations being recorded on a JASCO J-715 spectropolarimeter.

NTH-Rne-Gluc1, NTH-Rne-Gluc2, NTH-Rne-E429G-Gluc1, and NTH-Rne-E429-Gluc2 proteins were purified from NEB 5- $\alpha$ cells (New England Biolabs C2987I) harboring pNTH4-Gluc1, pNTH4-Gluc2, pNTH-E429G-Gluc1, and pNTH-E429G-Gluc2, respectively, using the Qiagen Ni-NTA fast start kit (Qiagen 30600) with an additional lysis step of $1 \mathrm{~min}$ of sonication and an additional wash step of $10 \mathrm{~mL}$ of $50 \mathrm{mM}$ IMD in wash buffer. The cultures were grown in $50 \mathrm{~mL}$ of $\mathrm{LB}$ with $1 \%$ glucose overnight, washed, diluted into $250 \mathrm{~mL}$ of fresh LB, grown for $1 \mathrm{~h}$, then induced with $1 \mathrm{mM}$ IPTG for $30 \mathrm{~min}$ and harvested. The harvested cells were washed with $1 \times \mathrm{TE}$ and frozen at $-80^{\circ} \mathrm{C}$ until protein purification. Purified protein was dialyzed into storage buffer $(50 \mathrm{mM}$ Tris- $\mathrm{HCl}$ at $\mathrm{pH} 7.5,500 \mathrm{mM} \mathrm{NaCl}, 1 \mathrm{mM}$ EDTA, 1 mM DTT, 30\% glycerol). The Bradford assay (Bradford reagent, Sigma-Aldrich B6916) was used to measure the concentrations of enzyme present in these preparations for calculation of concentrations used in in vitro analyses.
AmiC protein was purified from HG0213 cells harboring the pKAN6B-AmiC plasmid. The HG0213 strain is derived from KSL2000, with the chromosomal rne gene replaced by the chloramphenicol resistance gene, and cell viability is supported by the truncated RNase E (Rne-400), which is expressed from pRNE400 in the presence of $100 \mu \mathrm{M}$ of IPTG. Possible RNase E protein contamination is minimized using this strain since we observed that AmiC protein has little interaction with the Rne-395 truncated protein. The cells were grown to early-log phase with $100 \mu \mathrm{M}$ IPTG, induced with $0.1 \%$ arabinose for $3 \mathrm{~h}$, and harvested. NiNTA agarose (Qiagen) was used for purification with the same procedure as described above. The purified protein was dialyzed into AmiC storage buffer (10 mM Tris-Cl at pH 7.5, $200 \mathrm{mM}$ $\mathrm{KCl}, 0.1 \mathrm{mM}$ EDTA at $\mathrm{pH} 8.0,1 \mathrm{mM}$ DTT, $30 \%$ glycerol). The Bradford assay (Bradford reagent, Sigma-Aldrich B6916) was used to measure the concentrations of enzyme present in these preparations for calculation of concentrations used in in vitro analyses.

In vitro cleavage assays

The oligonucleotide BR10-hpT (5'-ACAGUAUUUGCAAA CAAACCACCGCUGGUAGCG GUGGUUUUUUUGUU- $3^{\prime}$ ) was synthesized by Bioneer and $5^{\prime}$ end-labeled with $\left[\gamma^{-}{ }^{32} \mathrm{P}\right]$-ATP and $\mathrm{T} 4$ polynucleotide kinase to generate $\mathrm{p}-\mathrm{BR} 10+\mathrm{hpT}$. Uniformly labeled $5^{\prime}$ triphosphorylated ppp-RNA I and ppp-p23 RNA with $\left[\alpha^{32} \mathrm{P}\right]-\mathrm{UTP}$ were synthesized as described previously (Lee et al. 2002; Shin et al. 2008). 5' end-labeled, monophosphorylated p-BR13, p-BR30, and p-23-13 (which were synthesized by Dharmacon) were generated as described previously (Feng et al. 2002). $5^{\prime}$ end-labeled, monophosphorylated RNA I was generated by synthesizing unlabeled ppp-RNA I as described previously (Lee et al. 2002), removing the $5^{\prime}$ triphosphate with CIP (Millipore Sigma P4978), and $5^{\prime}$ end-labeling with $\left[\gamma^{-}{ }^{32} \mathrm{P}\right]$-ATP and T4 
polynucleotide kinase. All cleavage assays were performed in $1 \times$ cleavage buffer $(20 \mathrm{mM}$ Tris- $\mathrm{Cl}$ at $\mathrm{pH} 7.5,10 \mathrm{mM} \mathrm{NaCl}, 10 \mathrm{mM}$ $\mathrm{MgCl}_{2}, 0.1 \mathrm{mM} \mathrm{DTT}$ ) at $37^{\circ} \mathrm{C}$. Samples were removed at the indicated times and were mixed with an equal volume of $2 \times$ RNA loading buffer $(0.025 \%$ xylene cyanol, $0.025 \%$ Bromophenol blue, $95 \%$ deionized formamide, $18 \mathrm{mM}$ EDTA at $\mathrm{pH} 8.0$, $0.025 \%$ SDS). Samples were denatured for $5 \mathrm{~min}$ at $75^{\circ} \mathrm{C}$ and were loaded onto various concentrations of polyacrylamide gels containing $8 \mathrm{M}$ urea $(12 \%$ polyacrylamide gels for $\mathrm{p}-\mathrm{BR} 13$ and $\mathrm{p}$ BR10+hpT RNAs, $8 \%$ polyacrylamide gels for ppp-RNA I and ppp-p23 RNAs). The radioactivity in each band was quantitated using a phosphorimager and OptiQuant software. The cleavage assay experiments were repeated three times and averaged. The error bars (standard errors of the mean) were used to indicate the range of assay results.

\section{EMSA RNA binding assays}

One picomole of uniformly labeled ppp-RNA I or ppp-p23 RNA was incubated with increasing amounts of purified NTH-Rne or NTH-Rne-E429G proteins (between $500 \mathrm{nM}$ and $5 \mu \mathrm{M}$ ) in $20 \mu \mathrm{L}$ of EMSA buffer (10 mM Tris- $\mathrm{HCl}$ at $\mathrm{pH} 7.5,0.1 \mathrm{mM}$ DTT, $1 \mathrm{mM}$ EDTA, $10 \%$ [v/v] glycerol), and analyzed using $8 \%$ PAGE. Binding constants were calculated from the slopes of the Scatchard plots.

\section{Luciferase assays}

We mixed 100 nM (50 nM Gluc1 + 50 nM Gluc2), 150 nM (75 nM Gluc1 + 75 nM Gluc2), 200 nM (100 nM Gluc1 + 100 nM Gluc2), $300 \mathrm{nM}$ (150 nM Gluc1 + $150 \mathrm{nM}$ Gluc2), and $400 \mathrm{nM}$ (200 nM Gluc1 + $200 \mathrm{nM}$ Gluc2) of fusions of either wild-type or E429G mutant NTH-Rne proteins in binding buffer $(20 \mathrm{mM}$ Tris-Cl at pH 8.0, 100 mM NaCl, 50 mM EDTA, 0.1 mM DTT). 1× Coelenterazine Native (NanoLight Technology) was added and luciferase activity was detected by Tecan. Each data point was normalized with a data point of $0 \mathrm{nM}$.

Purified NTH-Rne-Gluc1 and NTH-Rne-Gluc2 (both at $75 \mathrm{nM}$ ) were mixed with $75 \mathrm{nM}, 150 \mathrm{nM}, 300 \mathrm{nM}, 600 \mathrm{nM}, 900 \mathrm{nM}$, and $1200 \mathrm{nM}$ GST, NTH-Rne, or AmiC proteins in binding buffer (same as above), respectively. Coelenterazine Native $(1 \times$; NanoLight Technology) was added and luciferase activity was detected by Tecan. Each data point was normalized with a data point of 0 $\mathrm{nM}$. After generation of the data, it was discovered that the plasmids in the bacterial stocks used to purify the NTH-Rne-Gluc1 and NTH-Rne-Gluc2 proteins used for the AmiC experiment carried a point mutation conferring a $\mathrm{C} 471 \mathrm{Y}$ missense mutation. There were no detectable effects of the mutation on any enzyme property that we tested. Subsequent testing of the bacterial stocks used to purify NTH-Rne-Gluc1, NTH-Rne-Gluc2, NTH-RneE429G-Gluc1, and NTH-Rne-E429G-Gluc2 for the experiment described previously showed no evidence of this mutation.

\section{Measurement of $\beta$-galactosidase activity}

pKAN6B and pKAN6-amiC were transformed into CJ1825 (Jain et al. 2002). The cells were grown in the absence or presence of arabinose $(0 \%-0.1 \%)$ to express AmiC protein. $\beta$-Galactosidase activity in whole cells was determined as described (Miller 1992). Values represent the means of at least three independent experiments.

\section{Ligand fishing}

pKAN6B or pKAN6B-amiC plasmids were transformed into W3110 or HG1012 strains. The HG1012 strain is derived from
KSL2000, with pNRNE4 replaced by pNTH6, which expresses NTH-RNE without a histidine tag in the presence of IPTG. To pull down AmiC, Ni-NTA agarose was used with a procedure modified from that of protein purification. The cells were resuspended in lysis buffer $\left(50 \mathrm{mM} \mathrm{NaH}_{2} \mathrm{PO}_{4}, 300 \mathrm{mM} \mathrm{NaCl}, 5 \mathrm{mM}\right.$ imidazole at $\mathrm{pH} 8.0$ ) and opened three times by French Press at a pressure of $500 \mathrm{psi}$. The cell lysate was incubated for $1 \mathrm{~h}$ at $4^{\circ}$ $\mathrm{C}$ with Ni-NTA agarose. The protein-bound Ni-NTA agarose was washed with $80 \mathrm{mM}$ imidazole buffer three times and 150 $\mathrm{mM}$ imidazole buffer two times. The proteins were eluted from the resin using $300 \mathrm{mM}$ imidazole buffer (same as lysis buffer but $300 \mathrm{mM}$ imidazole).

\section{Crystal structure modeling}

The crystal structure of the "catalytic domain of E. coli RNase E in complex with 13-mer RNA" (PDB ID: 2COB), was downloaded from the RCSB Protein Data Bank (http://www.pdb.org) and visually examined using the PyMOL software (http://www.pymol .org, The PyMOL Molecular Graphics System, version 0.99rc6, Schrödinger, LLC.), which was used to generate all protein structure graphics. The mutants of E429 were modeled using the mutagenesis function of the PyMOL software.

\section{Acknowledgments}

We thank J. Belasco (New York University) for helpful discussions. We also thank Dr. Minho Lee and Dr. Minju Joo (ChungAng University) for technical assistance. This work was supported by grants from the National Research Foundation of Korea (NRF) to K.L. (grant no. 2018R1A5A1025077 and 2019R1A2C 2084563) and by National Institutes of Health grants 5R01GM54158 and 5R01AI08619 to S.N.C.

Author contributions: H.G., C.J.M., E.S., H.-J.H., S.S., N.-C.H., and Y.-H.K. carried out experiments. All authors designed experiments, analyzed data, and discussed results. C.J.M., H.G., S.N.C., and K.L. wrote the manuscript.

\section{References}

Ali N, Gowrishankar J. 2020. Cross-subunit catalysis and a new phenomenon of recessive resurrection in Escherichia coli RNase E. Nucleic Acids Res 48: 847-861. doi:10.1093/nar/ gkz1152

Altschul SF, Gish W, Miller W, Myers EW, Lipman DJ. 1990. Basic local alignment search tool. J Mol Biol 215: 403-410. doi:10 .1016/S0022-2836/05/80360-2

Anupama K, Leela JK, Gowrishankar J. 2011. Two pathways for RNase E action in Escherichia coli in vivo and bypass of its essentiality in mutants defective for Rho-dependent transcription termination. Mol Microbiol 82: 1330-1348. doi:10 $.1111 / j .1365-2958.2011 .07895 . x$

Baek YM, Jang KJ, Lee H, Yoon S, Baek A, Lee K, Kim DE. 2019. The bacterial endoribonuclease RNase E can cleave RNA in the absence of the RNA chaperone Hfq. I Biol Chem 294: 16465-16478. doi:10.1074/jbc.RA119.010105

Bandyra KJ, Luisi BF. 2018. RNase E and the high-fidelity orchestration of RNA metabolism. Microbiol Spectr doi:10.1128/ microbiolspec.RWR-0008-2017

Benson DA, Cavanaugh M, Clark K, Karsch-Mizrachi I, Lipman DJ, Ostell J, Sayers EW. 2013. Genbank. Nucleic Acids Res 41: D36-D42.

Bernhardt TG, de Boer PAJ. 2003. The Escherichia coli amidase AmiC is a periplasmic septal ring component exported via 
the twin-arginine transport pathway. Mol Microbiol 48: 11711182. doi:10.1046/j.1365-2958.2003.03511.x

Callaghan AJ, Marcaida MJ, Stead JA, McDowall KJ, Scott WG, Luisi BF. 2005a. Structure of Escherichia coli RNase E catalytic domain and implications for RNA turnover. Nature 437: 1187-1191. doi:10.1038/nature04084

Callaghan AJ, Redko Y, Murphy LM, Grossmann JG, Yates D, Garman E, Ilag LL, Robinson CV, Symmons MF, McDowall $\mathrm{KJ}$, et al. 2005b. 'Zn-link': a metal-sharing interface that organizes the quaternary structure and catalytic site of the endoribonuclease, RNase E. Biochemistry 44: 4667-4675. doi:10 $.1021 /$ bi0478244

Carpousis AJ, Luisi BF, McDowall KJ. 2009. Endonucleolytic initiation of mRNA decay in Escherichia coli. Prog Mol Biol Transl Sci 85: 91-135. doi:10.1016/S0079-6603/08/00803-9

Caruthers JM, Feng Y, McKay DB, Cohen SN. 2006. Retention of core catalytic functions by a conserved minimal ribonuclease E peptide that lacks the domain required for tetramer formation. I Biol Chem 281: 27046-27051. doi:10.1074/jbc .M602467200

Claverie-Martin F, Diaz-Torres MR, Yancey SD, Kushner SR. 1991. Analysis of the altered mRNA stability (ams) gene from Escherichia coli. Nucleotide sequence, transcriptional analysis, and homology of its product to MRP3, a mitochondrial ribosomal protein from Neurospora crassa. J Biol Chem 266: 2843-2851.

Datsenko KA, Wanner BL. 2000. One-step inactivation of chromosomal genes in Escherichia coli K-12 using PCR products. Proc Natl Acad Sci 97: 6640-6645. doi:10.1073/pnas .120163297

Feng Y, Vickers TA, Cohen SN. 2002. The catalytic domain of RNase E shows inherent $3^{\prime}$ to $5^{\prime}$ directionality in cleavage site selection. Proc Natl Acad Sci 99: 14746-14751. doi:10 $.1073 /$ pnas.202590899

Fink AL. 1998. Protein aggregation: folding aggregates, inclusion bodies and amyloid. Fold Des 3: R9-R23. doi:10.1016/S13590278(98)00002-9

Gao J, Lee K, Zhao M, Qiu J, Zhan X, Saxena A, Moore CJ, Cohen SN, Georgiou G. 2006. Differential modulation of E. coli mRNA abundance by inhibitory proteins that alter the composition of the degradosome. Mol Microbiol 61: 394-406. doi:10.1111/j.1365-2958.2006.05246.x

Garrey SM, Blech M, Riffell JL, Hankins JS, Stickney LM, Diver M, Hsu YH, Kunanithy V, Mackie GA. 2009. Substrate binding and active site residues in RNases E and G: role of the 5'-sensor. I Biol Chem 284: 31843-31850. doi:10.1074/jbc .M109.063263

Go H, Moore CJ, Lee M, Shin E, Jeon CO, Cha CJ, Han SH, Kim SJ, Lee SW, Lee Y, et al. 2011. Upregulation of RNase E activity by mutation of a site that uncompetitively interferes with RNA binding. RNA Biol 8: 1022-1034. doi:10.4161/rna.8.6.18063

Göpel Y, Papenfort K, Reichenbach B, Vogel J, Görke B. 2013. Targeted decay of a regulatory small RNA by an adaptor protein for RNase $\mathrm{E}$ and counteraction by an anti-adaptor RNA. Genes Dev 27: 552-564. doi:10.1101/gad.210112.112

Ize B, Stanley NR, Buchanan G, Palmer T. 2003. Role of the Escherichia coli Tat pathway in outer membrane integrity. Mol Microbiol 48: 1183-1193. doi:10.1046/j.1365-2958.2003 .03504.x

Jain C, Belasco JG. 1995. RNase E autoregulates its synthesis by controlling the degradation rate of its own mRNA in Escherichia coli: unusual sensitivity of the rne transcript to RNase E activity. Genes Dev 9: 84-96. doi:10.1101/gad.9.1.84
Jain C, Deana A, Belasco JG. 2002. Consequences of RNase E scarcity in Escherichia coli. Mol Microbiol 43: 1053-1064. doi:10 $.1046 / j .1365-2958.2002 .02808 . x$

Jiang X, Belasco JG. 2004. Catalytic activation of multimeric RNase E and RNase G by 5'-monophosphorylated RNA. Proc Nat1 Acad Sci 101: 9211-9216. doi:10.1073/pnas.0401382101

Jourdan SS, Kime L, McDowall KJ. 2010. The sequence of sites recognised by a member of the RNase E/G family can control the maximal rate of cleavage, while a $5^{\prime}$-monophosphorylated end appears to function cooperatively in mediating RNA binding. Biochem Biophys Res Commun 391: 879-883. doi:10 .1016/j.bbrc.2009.11.156

Kelly SM, Price NC. 2000. The use of circular dichroism in the investigation of protein structure and function. Curr Protein Pept Sci 1: 349-384. doi:10.2174/1389203003381315

Khemici V, Poljak L, Luisi BF, Carpousis AJ. 2008. The RNase E of Escherichia coli is a membrane-binding protein. Mol Microbiol 10: 799-813.

Kim S, Kim H, Park I, Lee Y. 1996. Mutational analysis of RNA structures and sequences postulated to affect $3^{\prime}$ processing of M1 RNA, the RNA component of Escherichia coli RNase P. J Biol Chem 271: 19330-19337. doi:10.1074/jbc.271.32.19330

Kim D, Kim Y-H, Jang J, Yeom J-H, Jun JW, Hyun S, Lee K. 2016. Functional analysis of Vibrio vulnificus orthologs of Escherichia coli RraA and RNase E. Curr Microbiol 72: 716-722. doi:10.1007/s00284-016-1007-y

Koslover DJ, Callaghan AJ, Marcaida MJ, Garman EF, Martick M, Scott WG, Luisi BF. 2008. The crystal structure of the Escherichia coli RNase E apoprotein and a mechanism for RNA degradation. Structure 16: 1238-1244. doi:10.1016/j.str.2008.04 .017

Lee K, Bernstein JA, Cohen SN. 2002. RNase G complementation of rne null mutation identifies functional interrelationships with RNase E in Escherichia coli. Mol Microbiol 43: 14451456. doi:10.1046/j.1365-2958.2002.02848.x

Lee K, Zhan X, Gao J, Qiu J, Feng Y, Meganathan R, Cohen SN, Georgiou G. 2003. RraA: a protein inhibitor of RNase E activity that globally modulates RNA abundance in E. coli. Cell 114: 623-634. doi:10.1016/j.cell.2003.08.003

Lin-Chao S, Cohen SN. 1991. The rate of processing and degradation of antisense RNAI regulates the replication of ColE1-type plasmids in vivo. Cell 65: 1233-1242. doi:10.1016/0092-8674 (91)90018-T

Lin-Chao S, Wong TT, McDowall KJ, Cohen SN. 1994. Effects of nucleotide sequence on the specificity of rne-dependent and RNase E-mediated cleavages of RNA I encoded by the pBR322 plasmid. J Biol Chem 269: 10797-10803.

Liou GG, Jane WN, Cohen SN, Lin NS, Lin-Chao S. 2001. RNA degradosomes exist in vivo in Escherichia coli as multicomponent complexes associated with the cytoplasmic membrane via the N-terminal region of ribonuclease E. Proc Natl Acad Sci 98: 63-68. doi:10.1073/pnas.98.1.63

Mackie GA. 1998. Ribonuclease E is a $5^{\prime}$-end-dependent endonuclease. Nature 395: 720-724. doi:10.1038/27246

Mackie GA. 2013. RNase E: at the interface of bacterial RNA processing and decay. Nat Rev Microbiol 11: 45-57. doi:10.1038/ nrmicro2930

McDowall KJ, Cohen SN. 1996. The N-terminal domain of the rne gene product has RNase E activity and is non-overlapping with the arginine-rich RNA-binding site. J Mol Biol 255: 349355. doi:10.1006/jmbi.1996.0027

McDowall KJ, Lin-Chao S, Cohen SN. 1994. A + U content rather than a particular nucleotide order determines the specificity of RNase E cleavage. J Biol Chem 269: 10790-10796. 
McDowall KJ, Kaberdin VR, Wu SW, Cohen SN, Lin-Chao S. 1995. Site-specific RNase E cleavage of oligonucleotides and inhibition by stem-loops. Nature 374: 287-290. doi:10.1038/ $374287 \mathrm{a} 0$

McWilliam H, Li W, Uludag M, Squizzato S, Park YM, Buso N, Cowley AP, Lopez R. 2013. Analysis tool web services from the EMBL-EBI. Nucleic Acids Res 41: W597-W600. doi:10 $.1093 / \mathrm{nar} / \mathrm{gkt} 376$

Miczak A, Srivastava RA, Apirion A. 1991. Location of the RNAprocessing enzymes RNase III, RNase $\mathrm{E}$ and RNase $\mathrm{P}$ in the Escherichia coli cell. Mol Microbiol 5: 1801-1810. doi:10 $.1111 / \mathrm{j} .1365-2958.1991 . t b 01929 . x$

Miller JH. 1992. A short course in bacterial genetics: a laboratory manual for Escherichia coli and related bacteria. Cold Spring Harbor Laboratory, Cold Spring Harbor, NY.

Mudd EA, Higgins CF. 1993. Escherichia coli endoribonuclease RNase E: autoregulation of expression and site-specific cleavage of mRNA. Mol Microbiol 9: 557-568. doi:10.1111/j.13652958.1993.tb01716.x

Ray BK, Singh B, Roy MK, Apirion D. 1982. Ribonuclease E is involved in the processing of 5-S rRNA from a number of rRNA transcription units. J Biochem 125: 283-289.

Remy I, Michnick SW. 2006. A highly sensitive protein-protein interaction assay based on Gaussia luciferase. Nat Methods 3: 977-979. doi:10.1038/nmeth979

Shin E, Go H, Yeom JH, Won M, Bae J, Han SH, Han K, Lee Y, Ha NC, Moore CI, et al. 2008. Identification of amino acid residues in the catalytic domain of RNase E essential for survival of Escherichia coli: functional analysis of DNase I subdomain. Genetics 179: 1871-1879. doi:10.1534/genetics.108.088492

Sikdar R, Doerrler WT. 2010. Inefficient Tat-dependent export of periplasmic amidases in an Escherichia coli strain with muta- tions in two DedA family genes. $J$ Bacteriol 192: 807-818. doi:10.1128/JB.00716-09

Singh D, Chang SJ, Lin PH, Averina OV, Kaberdin VR, Lin-Chao S. 2009. Regulation of ribonuclease E activity by the L4 ribosomal protein of Escherichia coli. Proc Natl Acad Sci 106: 864-869. doi:10.1073/pnas.0810205106

Sousa S, Marchand I, Dreyfus M. 2001. Autoregulation allows Escherichia coli RNase E to adjust continuously its synthesis to that of its substrates. Mol Microbiol 42: 867-878. doi:10 $.1046 / j .1365-2958.2001 .02687 . x$

Tamura M, Lee K, Miller CA, Moore CJ, Shirako Y, Kobayashi M, Cohen SN. 2006. RNase E maintenance of proper FtsZ/FtsA ratio required for nonfilamentous growth of Escherichia coli cells but not for colony-forming ability. I Bacteriol 188: 5145-5152. doi:10.1128/JB.00367-06

Vermassen A, Leroy S, Talon R, Provot C, Popowska M, Desvaux M. 2019. Cell wall hydrolases in bacteria: insight on the diversity of cell wall amidases, glycosidases and peptidases toward peptidoglycan. Front Microbiol 10: 331. doi:10.3389/fmicb .2019 .00331

Yeom JH, Lee K. 2006. RraA rescues Escherichia coli cells overproducing RNase $\mathrm{E}$ from growth arrest by modulating the ribonucleolytic activity. Biochem Biophys Res Commun 345: 1372-1376. doi:10.1016/j.bbrc.2006.05.018

Yeom JH, Go H, Shin E, Kim HL, Han SH, Moore CJ, Bae J, Lee K. 2008. Inhibitory effects of RraA and RraB on RNase E-related enzymes imply conserved functions in the regulated enzymatic cleavage of RNA. FEMS Microbiol. Lett 285: 10-15. doi:10 $.1111 / j .1574-6968.2008 .01205 . x$

Zhou HX, Pang X. 2018. Electrostatic interactions in protein structure, folding, binding, and condensation. Chem Rev 118: 1691-1741. doi:10.1021/acs.chemrev.7b00305 


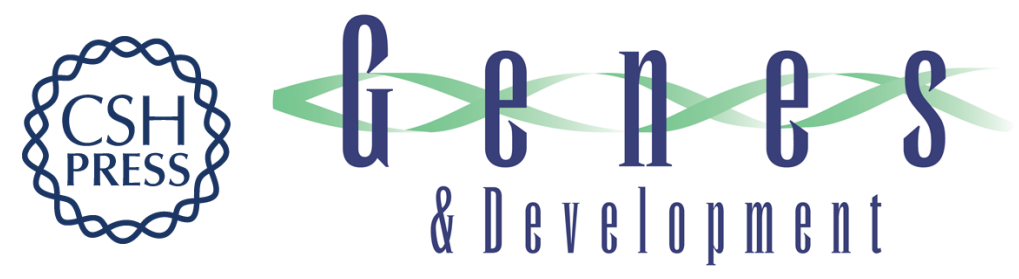

\section{Substrate-dependent effects of quaternary structure on RNase E activity}

Christopher J. Moore, Hayoung Go, Eunkyoung Shin, et al.

Genes Dev. 2021, 35: originally published online January 14, 2021

Access the most recent version at doi:10.1101/gad.335828.119

\section{Supplemental http://genesdev.cshlp.org/content/suppl/2021/01/13/gad.335828.119.DC1 Material}

References This article cites 53 articles, 16 of which can be accessed free at: http://genesdev.cshlp.org/content/35/3-4/286.full.html\#ref-list-1

Creative This article is distributed exclusively by Cold Spring Harbor Laboratory Press for the first Commons six months after the full-issue publication date (see

License http://genesdev.cshlp.org/site/misc/terms.xhtml). After six months, it is available under a Creative Commons License (Attribution-NonCommercial 4.0 International), as described at http://creativecommons.org/licenses/by-nc/4.0/.

Email Alerting Receive free email alerts when new articles cite this article - sign up in the box at the top Service right corner of the article or click here.

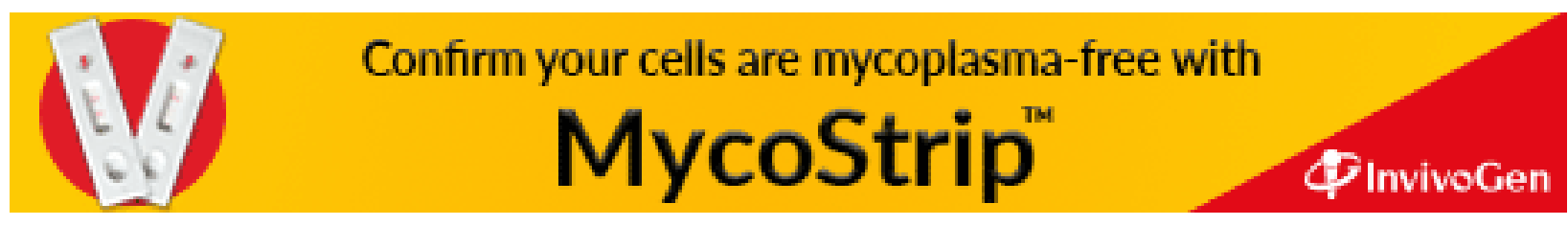

